Supporting information:

\title{
Structure Sensitivity in Steam and Dry Methane Reforming over Nickel: Activity and Carbon Formation
}

AUTHOR NAMES Charlotte Vogt, Jelle Kranenborg, Matteo Monai, Bert M. Weckhuysen*

AUTHOR ADDRESS Inorganic Chemistry and Catalysis group, Debye Institute for Nanomaterials Science, Utrecht University, Universiteitsweg 99, 3584 CG Utrecht, The Netherlands.

CORRESPONDANCE: B.M.Weckhuysen@uu.nl 


\section{Contents}

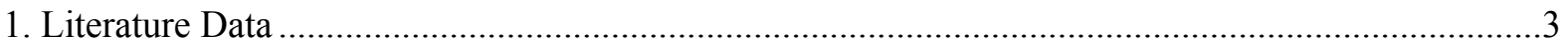

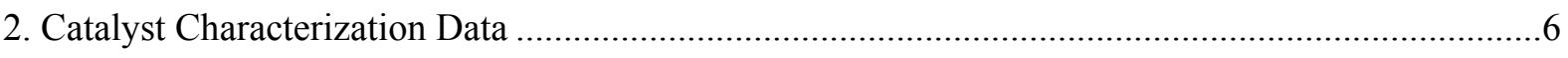

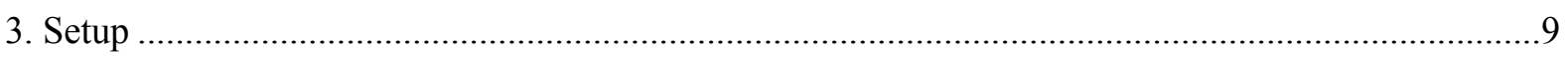

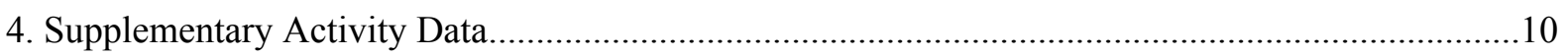

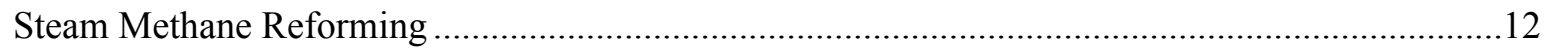

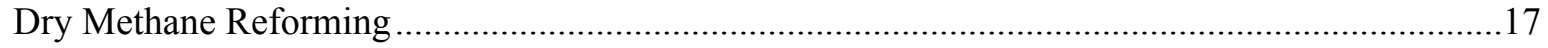

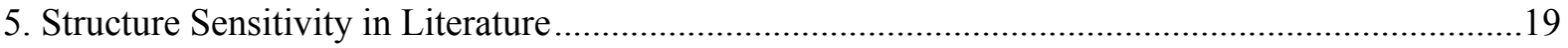

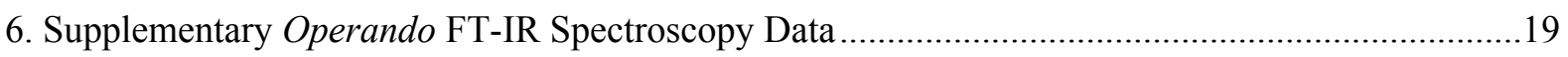

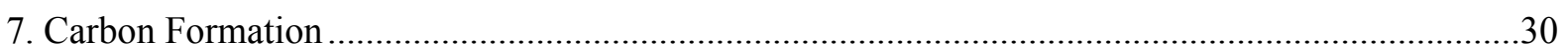

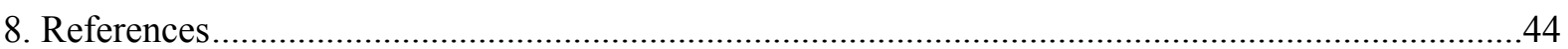



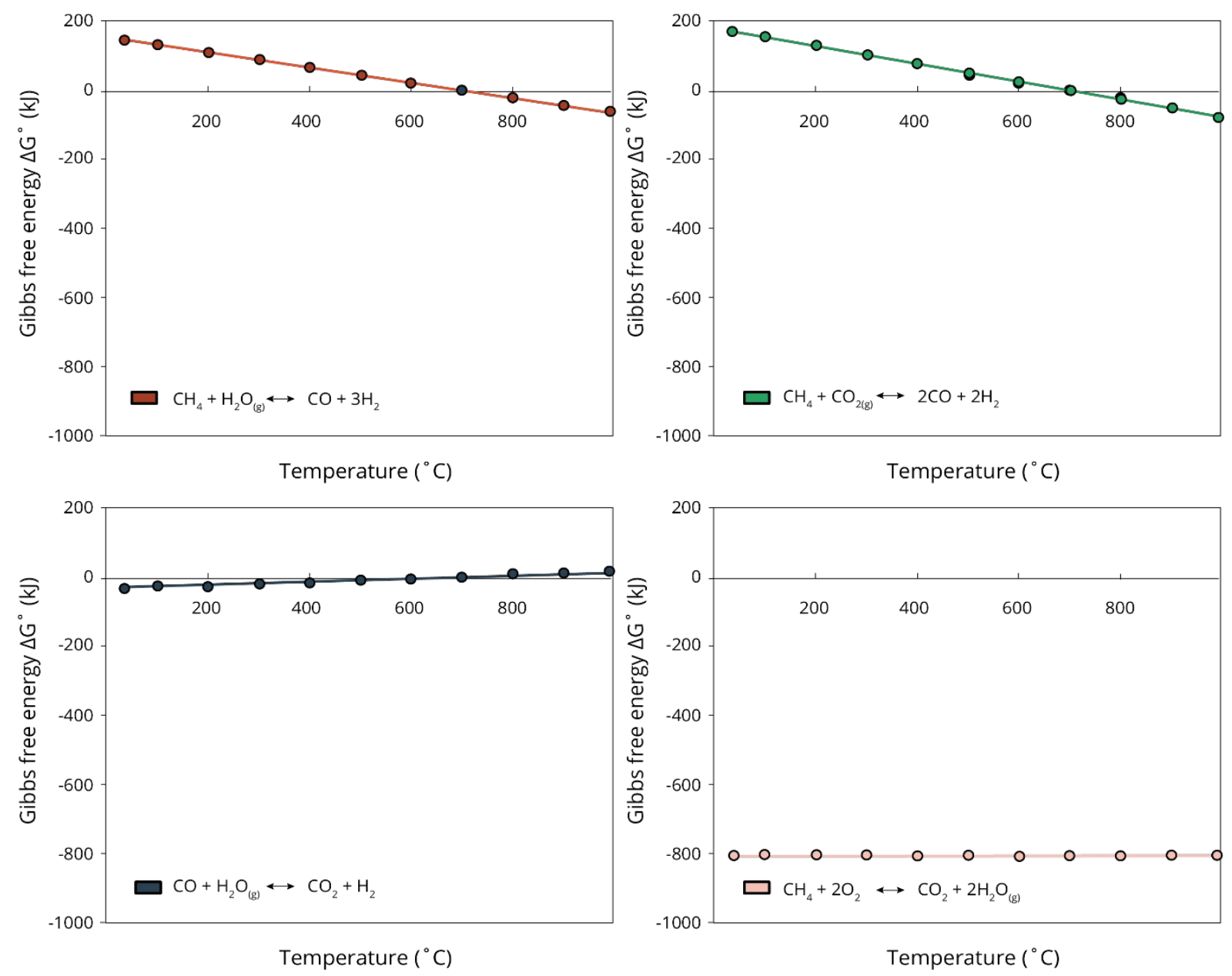

Figure S1. Thermodynamics of different relevant reactions. 

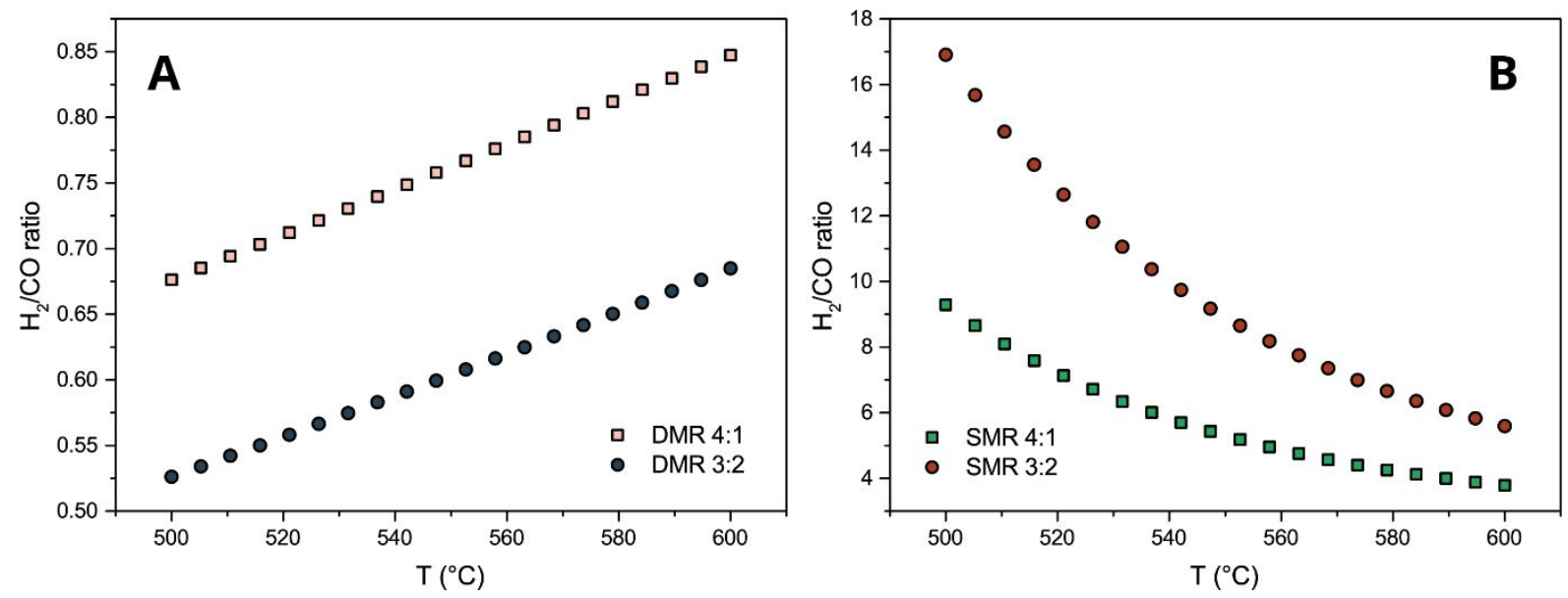

Figure S2. The $\mathrm{H}_{2} / \mathrm{CO}$ ratio that can be thermodynamically obtained in the presence of $\mathrm{CO}_{2}(\mathrm{DMR}, \mathrm{A})$ and $\mathrm{H}_{2} \mathrm{O}(\mathrm{SMR}, \mathrm{B})$. 


\section{Literature Data}

Table S1. Literature turnover frequency values for different metals in dry methane reforming.

\begin{tabular}{|c|c|c|c|c|}
\hline Catalyst & $\mathrm{T}\left({ }^{\circ} \mathrm{C}\right)$ & $\begin{array}{c}\text { Rhodium } \\
\text { Particle size (nm) }\end{array}$ & $\begin{array}{l}\mathrm{TOF}\left(\mathrm{CH}_{4}, \mathrm{~s}^{-}\right. \\
\left.{ }^{1}\right)\end{array}$ & Reference \\
\hline $\mathrm{Rh} / \mathrm{Al}_{2} \mathrm{O}_{3}$ & 600 & 2 & 6.1 & 1 \\
\hline $\mathrm{Rh} / \mathrm{Al}_{2} \mathrm{O}_{3}$ & 600 & 2.4 & 5.1 & 1 \\
\hline $\mathrm{Rh} / \mathrm{Al}_{2} \mathrm{O}_{3}$ & 600 & 3 & 4.2 & 1 \\
\hline $\mathrm{Rh} / \mathrm{Al}_{2} \mathrm{O}_{3}$ & 600 & 3.5 & 3.3 & 1 \\
\hline $\mathrm{Rh} / \mathrm{Al}_{2} \mathrm{O}_{3}$ & 600 & 4.3 & 2.4 & 1 \\
\hline $\mathrm{Rh} / \mathrm{ZrO}_{2}$ & 600 & 1.5 & 8.5 & 1 \\
\hline $\mathrm{Rh} / \mathrm{ZrO}_{2}$ & 600 & 1.8 & 7.8 & 1 \\
\hline $\mathrm{Rh} / \mathrm{ZrO}_{2}$ & 600 & 2.0 & 6.8 & 1 \\
\hline $\mathrm{Rh} / \mathrm{ZrO}_{2}$ & 600 & 2.2 & 5.5 & 1 \\
\hline $\mathrm{Rh} / \mathrm{ZrO}_{2}$ & 600 & 2.4 & 4.5 & 1 \\
\hline $\mathrm{Rh} / \mathrm{Al}_{2} \mathrm{O}_{3}$ & 600 & 3.5 & 1.2 & 2 \\
\hline $\mathrm{Rh} / \mathrm{Al}_{2} \mathrm{O}_{3}$ & 600 & 4.5 & 1.1 & 2 \\
\hline $\mathrm{Rh} / \mathrm{Al}_{2} \mathrm{O}_{3}$ & 600 & 9 & 1.4 & 2 \\
\hline $\mathrm{Rh} / \mathrm{Al}_{2} \mathrm{O}_{3}$ & 600 & 15 & 1.0 & 2 \\
\hline $\mathrm{Rh} / \mathrm{Al}_{2} \mathrm{O}_{3}$ & 650 & 1 & 13 & 3 \\
\hline $\mathrm{Rh} / \mathrm{Al}_{2} \mathrm{O}_{3}$ & 650 & 2.2 & 12.8 & 3 \\
\hline $\mathrm{Rh} / \mathrm{Al}_{2} \mathrm{O}_{3}$ & 650 & 3.3 & 8 & 3 \\
\hline $\mathrm{Rh} / \mathrm{Al}_{2} \mathrm{O}_{3}$ & 650 & 4 & 6 & 3 \\
\hline $\mathrm{Rh} / \mathrm{SiO}_{2}$ & 650 & 1.1 & 7 & 3 \\
\hline $\mathrm{Rh} / \mathrm{SiO}_{2}$ & 650 & 2.1 & 6 & 3 \\
\hline $\mathrm{Rh} / \mathrm{SiO}_{2}$ & 650 & 2.2 & 5.5 & 3 \\
\hline $\mathrm{Rh} / \mathrm{SiO}_{2}$ & 650 & 5 & 9 & 3 \\
\hline $\mathrm{Rh} / \mathrm{TiO}_{2}$ & 650 & 27 & 1.1 & 3 \\
\hline $\mathrm{Rh} / \mathrm{TiO}_{2}$ & 650 & 20 & 1.8 & 3 \\
\hline $\mathrm{Rh} / \mathrm{TiO}_{2}$ & 650 & 12 & 1.7 & 3 \\
\hline $\mathrm{Rh} / \mathrm{TiO}_{2}$ & 650 & 4 & 3.7 & 3 \\
\hline $\mathrm{Rh} / \mathrm{TiO}_{2}$ & 650 & 6 & 5 & 3 \\
\hline $\mathrm{Rh} / \mathrm{La}_{2} \mathrm{O}_{3}$ & 650 & 5.5 & 6.0 & 3 \\
\hline $\mathrm{Rh} / \mathrm{MgO}$ & 650 & 2.2 & 0.8 & 3 \\
\hline \multicolumn{5}{|c|}{ Platinum } \\
\hline Catalyst & $\mathrm{T}\left({ }^{\circ} \mathrm{C}\right)$ & Particle size (nm) & $\begin{array}{l}\text { TOF }\left(\mathrm{CH}_{4}, \mathrm{~s}^{-}\right. \\
\text {1) }\end{array}$ & Reference \\
\hline $\mathrm{Pt} / \mathrm{ZrO}_{2}-\mathrm{CeO}_{2}$ & 600 & 1.7 & 23.8 & 4 \\
\hline $\mathrm{Pt} / \mathrm{ZrO}_{2}-\mathrm{CeO}_{2}$ & 600 & 2.3 & 21.1 & 4 \\
\hline $\mathrm{Pt} / \mathrm{ZrO}_{2}-\mathrm{CeO}_{2}$ & 600 & 2.9 & 18.6 & 4 \\
\hline $\mathrm{Pt} / \mathrm{ZrO}_{2}-\mathrm{CeO}_{2}$ & 600 & 3.9 & 15.0 & 4 \\
\hline $\mathrm{Pt} / \mathrm{ZrO}_{2}$ & 600 & 3.6 & 16.4 & 4 \\
\hline $\mathrm{Pt} / \mathrm{ZrO}_{2}$ & 600 & 6.3 & 12.8 & 4 \\
\hline Catalyst & $\mathrm{T}\left({ }^{\circ} \mathrm{C}\right)$ & $\begin{array}{c}\text { Iridium } \\
\text { Particle size (nm) }\end{array}$ & $\begin{array}{l}\mathrm{TOF}\left(\mathrm{CH}_{4}, \mathrm{~s}^{-}\right. \\
\left.{ }^{1}\right)\end{array}$ & Reference \\
\hline $\mathrm{Ir} / \mathrm{Al}_{2} \mathrm{O}_{3}$ & 700 & 2 & 2 & 2 \\
\hline $\mathrm{Ir} / \mathrm{Al}_{2} \mathrm{O}_{3}$ & 700 & 2.2 & 2.2 & 2 \\
\hline $\mathrm{Ir} / \mathrm{Al}_{2} \mathrm{O}_{3}$ & 700 & 4.5 & 4.5 & 2 \\
\hline $\mathrm{Ir} / \mathrm{Al}_{2} \mathrm{O}_{3}$ & 700 & 7 & 7 & 2 \\
\hline $\mathrm{IR} / \mathrm{ZrO}_{2}$ & 600 & 2.2 & 13.0 & 5 \\
\hline Catalyst & $\mathrm{T}\left({ }^{\circ} \mathrm{C}\right)$ & $\begin{array}{c}\text { Ruthenium } \\
\text { Particle size (nm) }\end{array}$ & $\begin{array}{l}\text { TOF }\left(\mathrm{CH}_{4}, \mathrm{~s}^{-}\right. \\
\left.{ }^{1}\right)\end{array}$ & Reference \\
\hline $\mathrm{Ru} / \mathrm{Al}_{2} \mathrm{O}_{3}$ & 600 & 2 & 4.5 & 4 \\
\hline $\mathrm{Ru} / \mathrm{Al}_{2} \mathrm{O}_{3}$ & 600 & 2.6 & 2.8 & 4 \\
\hline
\end{tabular}


$\mathrm{Ru} / \mathrm{Al}_{2} \mathrm{O}_{3}$

4 
Table S2. Literature turnover frequency values for different metals in steam methane reforming.

\begin{tabular}{|c|c|c|c|c|}
\hline \multicolumn{5}{|c|}{ Rhodium } \\
\hline $\mathrm{Rh} / \mathrm{Al}_{2} \mathrm{O}_{3}$ & 600 & 2 & 5.7 & 1 \\
\hline $\mathrm{Rh} / \mathrm{Al}_{2} \mathrm{O}_{3}$ & 600 & 2.4 & 5.2 & 1 \\
\hline $\mathrm{Rh} / \mathrm{Al}_{2} \mathrm{O}_{3}$ & 600 & 3 & 4.1 & 1 \\
\hline $\mathrm{Rh} / \mathrm{Al}_{2} \mathrm{O}_{3}$ & 600 & 3.5 & 3.0 & 1 \\
\hline $\mathrm{Rh} / \mathrm{Al}_{2} \mathrm{O}_{3}$ & 600 & 4.3 & 2.2 & 1 \\
\hline $\mathrm{Rh} / \mathrm{ZrO}_{2}$ & 600 & 1.5 & 9.0 & 1 \\
\hline $\mathrm{Rh} / \mathrm{ZrO}_{2}$ & 600 & 1.8 & 7.8 & 1 \\
\hline $\mathrm{Rh} / \mathrm{ZrO}_{2}$ & 600 & 2.0 & 7 & 1 \\
\hline $\mathrm{Rh} / \mathrm{ZrO}_{2}$ & 600 & 2.2 & 6.1 & 1 \\
\hline $\mathrm{Rh} / \mathrm{ZrO}_{2}$ & 600 & 2.4 & 5 & 1 \\
\hline $\mathrm{Rh} / \mathrm{FAl}$ & 600 & 1.6 & 17.8 & 6 \\
\hline $\mathrm{Rh} / \mathrm{SAl}$ & 600 & 1.8 & 24.6 & 6 \\
\hline $\mathrm{Rh} / \mathrm{FAl}$ & 600 & 1.5 & 17.1 & 6 \\
\hline $\mathrm{Rh} / \mathrm{SAl}$ & 600 & 1.5 & 21.5 & 6 \\
\hline $\mathrm{Rh}-\mathrm{Ni} / \mathrm{Al}_{2} \mathrm{O}_{3}$ & 525 & 15 & 1.6 & 7 \\
\hline \multicolumn{5}{|c|}{ Platinum } \\
\hline Catalyst & $\mathrm{T}\left({ }^{\circ} \mathrm{C}\right)$ & Particle size $(\mathrm{nm})$ & TOF $\left(\mathrm{CH}_{4}, \mathrm{~s}^{-1}\right)$ & Reference \\
\hline $\mathrm{Pt} / \mathrm{ZrO}_{2}-\mathrm{CeO}_{2}$ & 600 & 2.0 & 24.7 & 8 \\
\hline $\mathrm{Pt} / \mathrm{ZrO}_{2}-\mathrm{CeO}_{2}$ & 600 & 2.1 & 22.5 & 8 \\
\hline $\mathrm{Pt} / \mathrm{ZrO}_{2}-\mathrm{CeO}_{2}$ & 600 & 3.0 & 19.5 & 8 \\
\hline $\mathrm{Pt} / \mathrm{ZrO}_{2}-\mathrm{CeO}_{2}$ & 600 & 3.8 & 14.8 & 8 \\
\hline $\mathrm{Pt} / \mathrm{ZrO}_{2}$ & 600 & 2.7 & 19 & 8 \\
\hline $\mathrm{Pt} / \mathrm{ZrO}_{2}$ & 600 & 4.5 & 16.3 & 8 \\
\hline $\mathrm{Pt} / \mathrm{ZrO}_{2}$ & 600 & 6.2 & 14 & 8 \\
\hline $\mathrm{Pt} / \mathrm{Al}_{2} \mathrm{O}_{3}$ & 600 & 4.5 & 15 & 8 \\
\hline $\mathrm{Pt} / \mathrm{Al}_{2} \mathrm{O}_{3}$ & 600 & 2.9 & 19.8 & 8 \\
\hline $\mathrm{Pt} / \mathrm{Al}_{2} \mathrm{O}_{3}$ & 600 & 4.5 & 15 & 8 \\
\hline $\mathrm{Pt} / \mathrm{Al}_{2} \mathrm{O}_{3}$ & 600 & 2.9 & 19.8 & 8 \\
\hline \multicolumn{5}{|c|}{ Iridium } \\
\hline Catalyst & $\mathrm{T}\left({ }^{\circ} \mathrm{C}\right)$ & Particle size (nm) & TOF $\left(\mathrm{CH}_{4}, \mathrm{~s}^{-1}\right)$ & Reference \\
\hline $\mathrm{Ir} / \mathrm{ZrO}_{2}$ & 600 & 2.2 & 12.4 & 5 \\
\hline \multicolumn{5}{|c|}{ Palladium } \\
\hline Catalyst & $\mathrm{T}\left({ }^{\circ} \mathrm{C}\right)$ & Particle size (nm) & TOF $\left(\mathrm{CH}_{4}, \mathrm{~s}^{-1}\right)$ & Reference \\
\hline $\mathrm{Pd} / \mathrm{CeO}_{2}-\mathrm{Al}_{2} \mathrm{O}_{3}$ & 510 & 7.6 & 4.7 & 9 \\
\hline $\mathrm{Pd} / \mathrm{Al}_{2} \mathrm{O}_{3}$ & 510 & & 0.91 & 9 \\
\hline $\mathrm{Pd} / \mathrm{CeO}_{2}$ & 510 & 30 & 4.1 & 9 \\
\hline $\mathrm{Pd} / 6 \mathrm{CeO}_{2}-\mathrm{Al}_{2} \mathrm{O}_{3}$ & 510 & 6.2 & 3.2 & 9 \\
\hline $\mathrm{Pd} / 12 \mathrm{CeO}_{2}-\mathrm{Al}_{2} \mathrm{O}_{3}$ & 510 & 7.6 & 1.8 & 9 \\
\hline \multicolumn{5}{|c|}{ Nickel } \\
\hline Catalyst & $\mathrm{T}\left({ }^{\circ} \mathrm{C}\right)$ & Particle size (nm) & TOF $\left(\mathrm{CH}_{4}, \mathrm{~s}^{-1}\right)$ & Reference \\
\hline $\mathrm{Ni} / \mathrm{MgO}$ & 600 & 6.7 & 3.5 & 10 \\
\hline $\mathrm{Ni} / \mathrm{MgO}$ & 650 & 6.7 & 8.8 & 10 \\
\hline $\mathrm{Ni} / \mathrm{MgO}$ & 700 & 6.7 & 19.0 & 10 \\
\hline
\end{tabular}




\section{Catalyst Characterization Data}

Table S3. Characteristics of the set of well-defined $\mathrm{Ni} / \mathrm{SiO}_{2}$ catalysts (1-6), listing their Ni loadings, and Ni mean particle sizes after reduction, and of spent catalysts as determined by HAADF-STEM, XRD, and XAS. This table, and full details on the characterization are reported elsewhere ${ }^{11}$.

\begin{tabular}{llllll}
\hline Sample $^{\mathrm{a}}$ & $\begin{array}{l}\text { Ni loading } \\
(\mathrm{wt} \%)\end{array}$ & $\begin{array}{l}\text { Ni HAADF-STEM } \\
\text { mean particle size } \\
\text { after reduction }(\mathrm{nm})^{\mathrm{b}}\end{array}$ & $\begin{array}{l}\text { Ni XAS } \\
\text { coordination number } \\
\text { particle size }) \text { after }_{\text {reduction }^{12,13 \mathrm{c}}}\end{array}$ & $\begin{array}{l}\text { NiO XRD mean } \\
\text { particle size } \\
\text { after reduction } \\
(\mathrm{nm})^{\mathrm{d}}\end{array}$ & $\begin{array}{l}\text { Sample code } \\
\text { in }^{11}\end{array}$ \\
\hline 1 & 4.7 & $1.2 \pm 0.5$ & $7.1 \pm 1.5(1.5 \mathrm{~nm})$ & $1.2 \pm 1.0$ & $\mathrm{C}$ \\
2 & 5.0 & $1.4 \pm 0.4$ & $7.3 \pm 1.2(2 \mathrm{~nm})$ & $2.0 \pm 0.5$ & $\mathrm{~B}$ \\
3 & 6.7 & $2.0 \pm 0.8$ & $7.6 \pm 1.3(2 \mathrm{~nm})$ & $0.9 \pm 0.2$ & $\mathrm{D}$ \\
4 & 11.8 & $2.1 \pm 1.1$ & $7.3 \pm 2.1(2 \mathrm{~nm})$ & $2.3 \pm 1.2$ & $\mathrm{~F}$ \\
5 & 19.5 & $4.4 \pm 2.4$ & $7.4 \pm 1.3(2 \mathrm{~nm})$ & $4.2 \pm 1.6$ & $\mathrm{G}$ \\
6 & 60.0 & $6.0 \pm 1.9$ & $8.8 \pm 1.1(6 \mathrm{~nm})$ & $5.2 \pm 2.6$ & $\mathrm{H}$
\end{tabular}

a Arbitrary codes denoted from smallest (1) to largest (6) catalyst particle sizes as determined from the spent NiO particle sizes from TEM, ${ }^{\mathrm{b}}$ Particle size distributions determined after reduction step (and re-oxidation by exposure to air) of at least 120 nanoparticles, see Vogt et al. ${ }^{11}$ for additional details on HAADF-STEM analysis, ${ }^{c}$ XAS particle sizes (in brackets) determined from coordination numbers ex-situ for particles after the respective reduction step (fit of first coordination shell) ${ }^{\mathrm{d}}$ Full-width at half-maximum (FWHM) X-ray diffraction analysis of the average of the 52 and $74^{\circ}$ diffraction peak of catalysts after reduction step, and re-oxidation by exposure to air. ${ }^{13,14}$ 

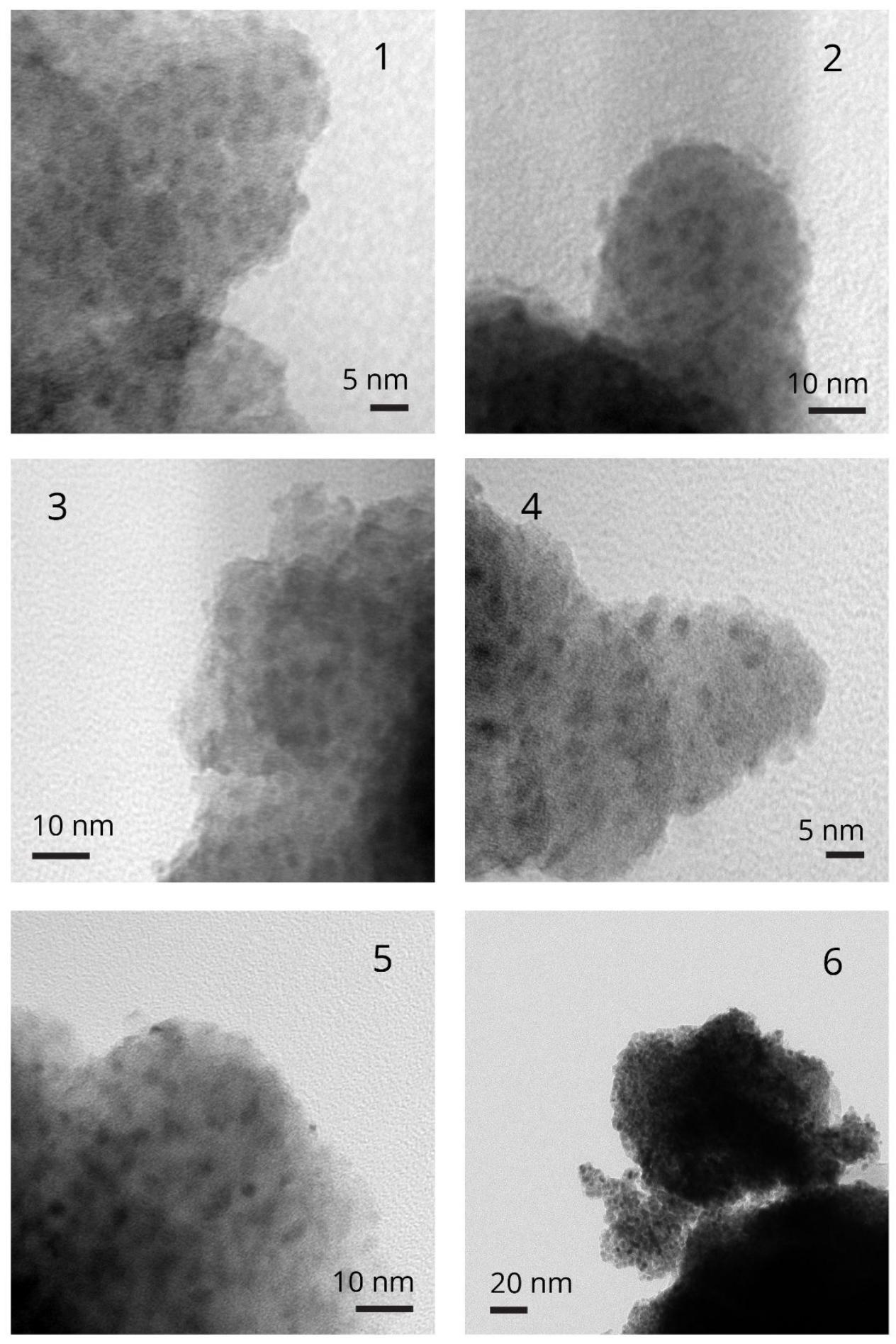

Figure S3. Transmission electron microscopy images of $\mathrm{Ni} / \mathrm{SiO}_{2}$ catalysts $1-6$ after reduction. 

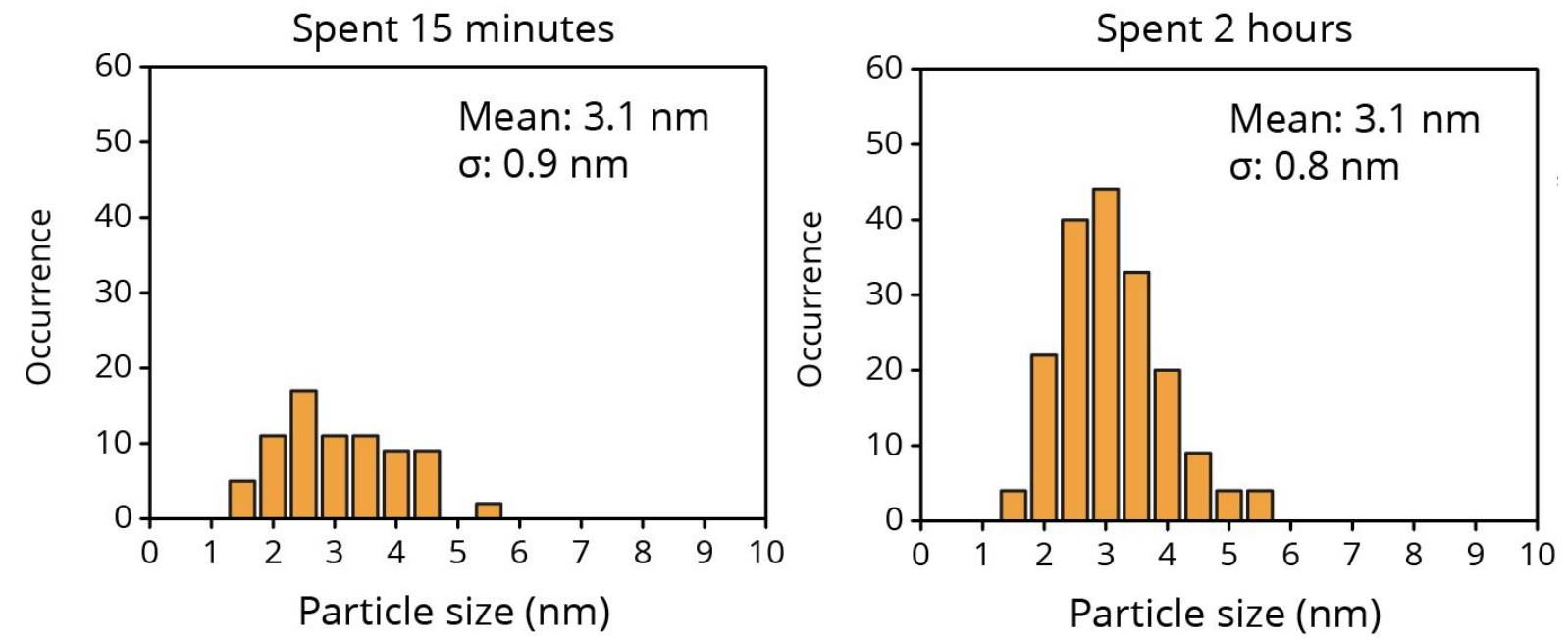

Figure S4. Particle size analysis of $15 \mathrm{~min}$ into reaction versus total experiment spent catalyst. 


\section{Setup}

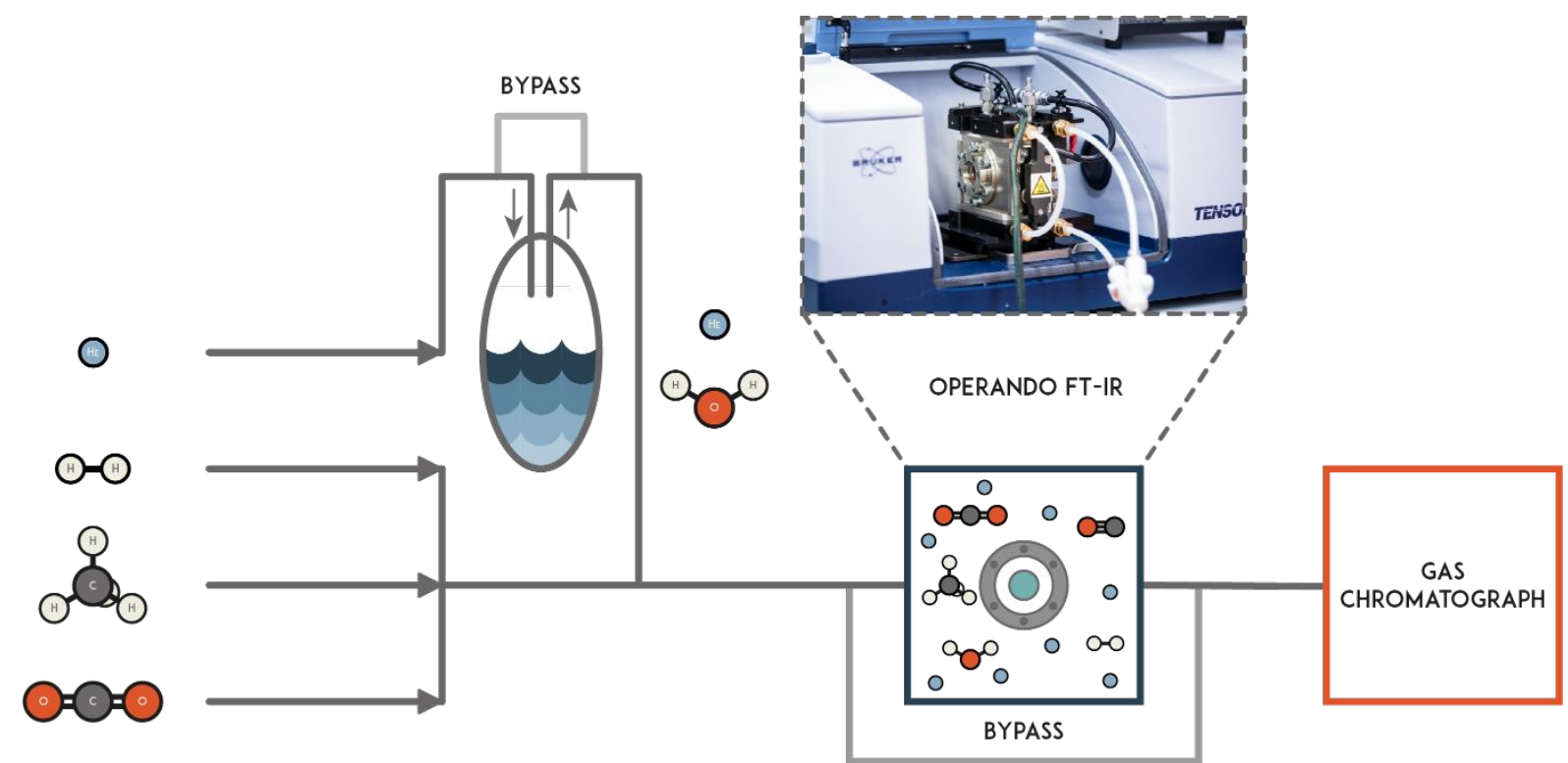

Figure S5. Schematic overview of the experimental setup used for operando FT-IR spectroscopy measurements to study (mainly) reaction intermediates and on-line gas chromatography to study product formation. 


\section{Supplementary Activity Data}

To perform the 4:1 $\mathrm{CH}_{4}: \mathrm{H}_{2} \mathrm{O}$ experiments, $9.1 \mathrm{~mL} \mathrm{~min}^{-1}$ was flowed. The stainless steel saturator with Milli-Q water (see Figure S3) was heated to $70{ }^{\circ} \mathrm{C}$. Under these conditions, $2.1 \mathrm{~mL} \mathrm{~min}^{-1}$ is present in the reactant feed. For the 3:2 ratio experiments, the methane flow was decreased to $5.75 \mathrm{~mL} \mathrm{~min}^{-1}$ and the temperature of the saturator was increased to $87^{\circ} \mathrm{C}$. For DMR, the same ratios between reactants as in SMR were applied. Yet no saturator was needed as $\mathrm{CO}_{2}$ is gaseous. For both ratios, methane was set at $9.1 \mathrm{~mL} \mathrm{~min}^{-1}$. For a ratio of $4: 1$, the $\mathrm{CO}_{2}$ flow was set on $2.7 \mathrm{~mL} \mathrm{~min}{ }^{-1}$, versus $6.8 \mathrm{~mL} \mathrm{~min}^{-1}$ for a ratio of 3:2. Gas- and weight hourly space velocities (GHSV and WHSV respectively) for both SMR and DMR at both ratios between reactants can be found in Table S4 and S5 respectively.

Table S4. Gas hourly space velocities (GHSV) for each experiment for both steam methane reforming (SMR) and dry methane reforming (DMR) at both ratios between reactants.

\begin{tabular}{llll}
$\begin{array}{l}\text { GHSV SMR 4:1 } \\
\left(\mathrm{h}^{-1}\right)\end{array}$ & $\begin{array}{l}\text { GHSV SMR 3:2 } \\
\left(\mathrm{h}^{-1}\right)\end{array}$ & $\begin{array}{l}\text { GHSV DMR 4:1 } \\
\left(\mathrm{h}^{-1}\right)\end{array}$ & $\begin{array}{l}\text { GHSV DMR 3:2 } \\
\left(\mathrm{h}^{-1}\right)\end{array}$ \\
\hline 33.5 & 32.5 & 34.0 & 37.0
\end{tabular}

Table S5. Weight hourly space velocities (WHSV) for each catalyst for every experiment for both steam methane reforming (SMR) and dry methane reforming (DMR).

\begin{tabular}{lllll} 
Catalyst & $\begin{array}{l}\text { WHSV SMR 4:1 } \\
\left(\mathrm{mL} \mathrm{g}^{-1} \mathrm{~h}^{-1}\right)\end{array}$ & $\begin{array}{l}\text { WHSV SMR 3:2 } \\
\left(\mathrm{mL} \mathrm{g}^{-1} \mathrm{~h}^{-1}\right)\end{array}$ & $\begin{array}{l}\text { WHSV DMR 4:1 } \\
\left(\mathrm{mL} \mathrm{g}^{-1} \mathrm{~h}^{-1}\right)\end{array}$ & $\begin{array}{l}\text { WHSV DMR 3:2 } \\
\left(\mathrm{mL} \mathrm{g}^{-1} \mathrm{~h}^{-1}\right)\end{array}$ \\
\hline 1 & 4140000 & 5570000 & 5310000 & 6270000 \\
2 & 4580000 & 5560000 & 5770000 & 5400000 \\
3 & 3990000 & 3730000 & 4010000 & 4370000 \\
4 & 2430000 & 1840000 & 1600000 & 1670000 \\
5 & 1300000 & 997000 & 1100000 & 1100000 \\
6 & 268000 & 312000 & 322000 & 436000
\end{tabular}


Table S6. Summary of all averaged conversions, and the thermodynamic maximum conversions with, and without coke. This table shows to prove that all values are below the thermodynamic maximum, except occasionally for catalyst 6 which in those cases is still far below the thermodynamic maximum conversion with coke.

\begin{tabular}{|c|c|c|c|c|c|c|c|c|}
\hline & 1 & 2 & 3 & 4 & 5 & 6 & $\begin{array}{l}\text { Thermodynamic } \\
\text { maximum without } \\
\text { coke }\end{array}$ & $\begin{array}{l}\text { Thermodynamic } \\
\text { maximum with coke }\end{array}$ \\
\hline \multicolumn{9}{|c|}{$\mathrm{SMR} \mathrm{mol} \mathrm{C} \cdot \mathrm{s}^{-1} 4: 1$} \\
\hline Average $\left(500^{\circ} \mathrm{C}\right)$ & 5.3 & 6.8 & 7.8 & 6.6 & 8.5 & 9.0 & 8.3 & 38.3 \\
\hline Average $\left(600^{\circ} \mathrm{C}\right)$ & 11.7 & 13.2 & 11.9 & 10.4 & 13.5 & 17.3 & 16.2 & 59.8 \\
\hline \multicolumn{9}{|c|}{$\mathrm{SMR} \mathrm{mol} \mathrm{C} \cdot \mathrm{s}^{-1} 3: 2$} \\
\hline Average $\left(500^{\circ} \mathrm{C}\right)$ & 8.2 & 9.8 & 9.3 & 10.0 & 9.7 & 9.1 & 16.5 & 33.9 \\
\hline Average $\left(600^{\circ} \mathrm{C}\right)$ & 25.8 & 20.0 & 24.2 & 25.3 & 28.3 & 28.3 & 32.3 & 57.4 \\
\hline \multicolumn{9}{|c|}{ DMR mol C $\cdot \mathrm{s}^{-1} 4: 1$} \\
\hline Average $\left(500{ }^{\circ} \mathrm{C}\right)$ & 4.3 & 4.8 & 6.2 & 6.8 & 6.9 & 9.2 & 7.1 & 56.7 \\
\hline Average $\left(600^{\circ} \mathrm{C}\right)$ & 7.8 & 8.4 & 8.9 & 12.0 & 13.0 & 19.9 & 18.0 & 71.6 \\
\hline \multicolumn{9}{|c|}{ DMR $\mathrm{mol} \mathrm{C} \cdot \mathrm{s}^{-1} 3: 2$} \\
\hline Average $\left(500^{\circ} \mathrm{C}\right)$ & 5.2 & 5.6 & 4.6 & 6.0 & 7.1 & 8.0 & 10.0 & 68.7 \\
\hline Average $\left(600{ }^{\circ} \mathrm{C}\right)$ & 9.6 & 10.8 & 11.0 & 13.6 & 16.8 & 20.1 & 26.9 & 78.6 \\
\hline
\end{tabular}

The thermodynamic equilibrium for the components observed during SMR and DMR reactions was calculated in the temperature range of $500-600^{\circ} \mathrm{C}$ at 5 bar, with varying feed composition, using Outotec software HSC Chemistry 7 and the integrated "Gibbs Energy Minimization Routine" algorithm (Gibbs 7.1).

Table S7. Maximum turnover frequency towards $\mathrm{CO}$ that theoretically could be obtained for each of the $\mathrm{Ni} / \mathrm{SiO}_{2}$ catalysts in steam and dry methane reforming.

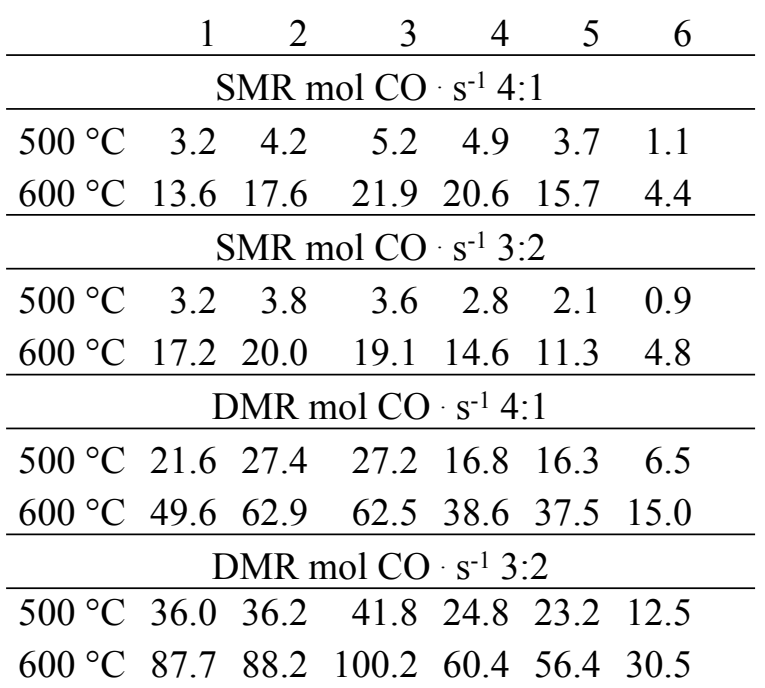




\section{Steam Methane Reforming}
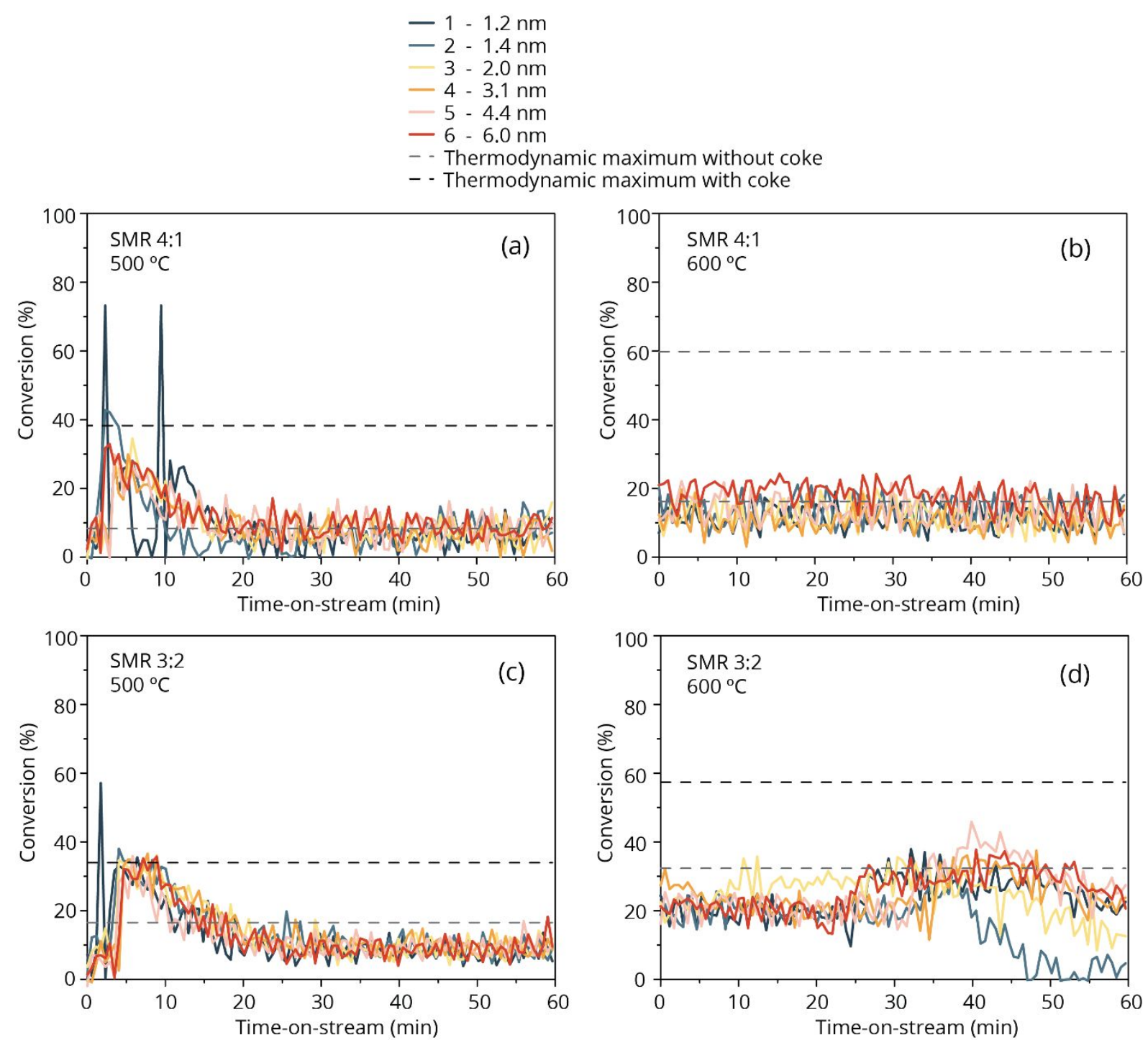

Figure S6. Conversion against time on stream for steam methane reforming (SMR) Ni/SiO 2 catalysts $1-6$, at 500 and $600{ }^{\circ} \mathrm{C}$. and at a feedstock ratio of $4: 1$ and $3: 2$ of $\mathrm{CH}_{4}: \mathrm{H}_{2} \mathrm{O}$. 

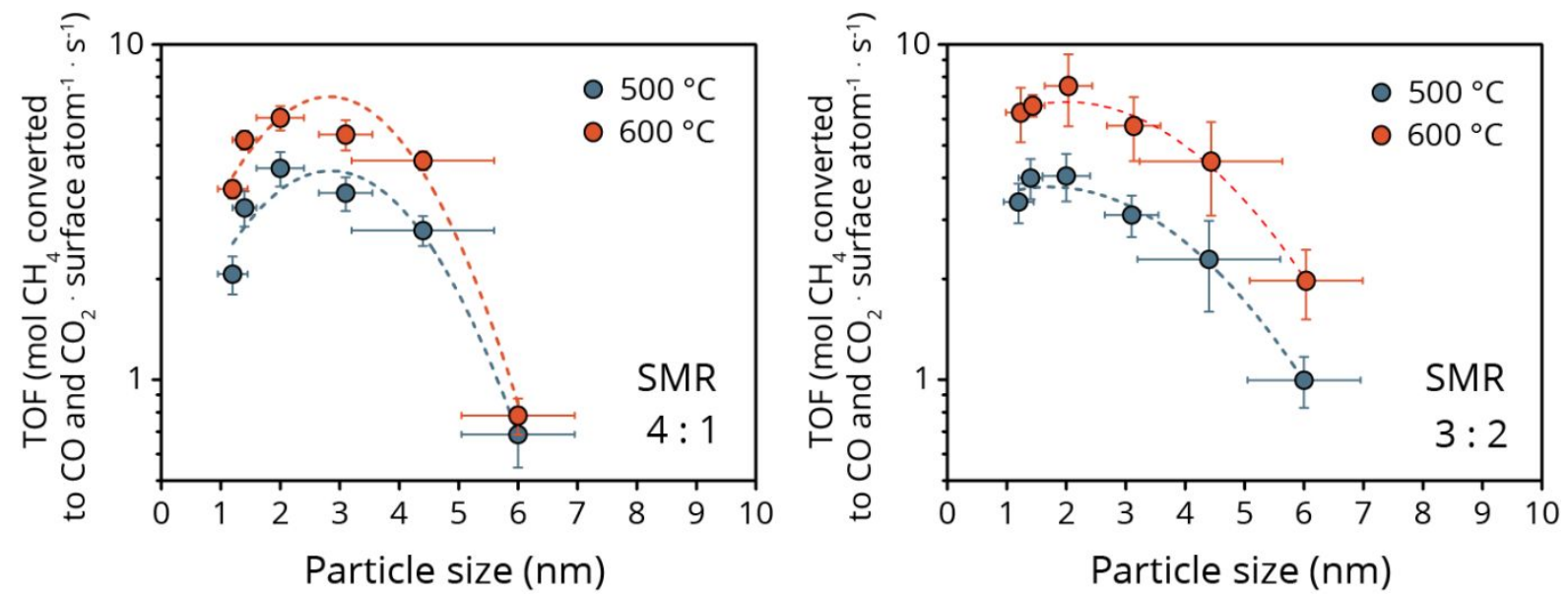

Figure S7. The influence of particle size on the turnover frequency (TOF) for $\mathrm{CO}$ and $\mathrm{CO}_{2}$ combined, at 500 (blue) and 600 ${ }^{\circ} \mathrm{C}$ (red) at 5 bar.
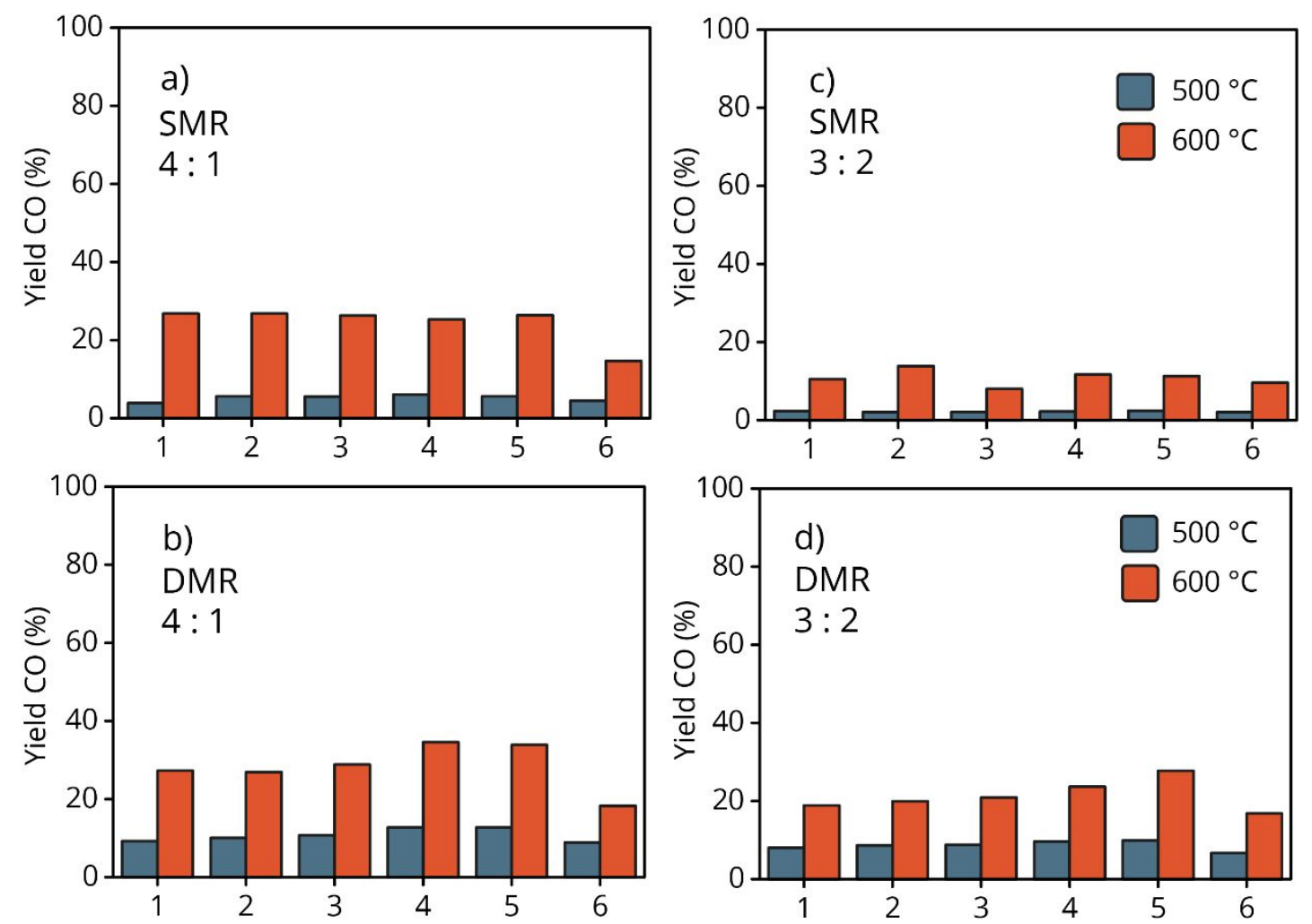

Figure S8. $\mathrm{CO}$ yield during steam methane reforming (SMR) and dry methane reforming (DMR) for $\mathrm{Ni} / \mathrm{SiO}_{2}$ catalysts $1-6$, at 500 and $600{ }^{\circ} \mathrm{C}$. 

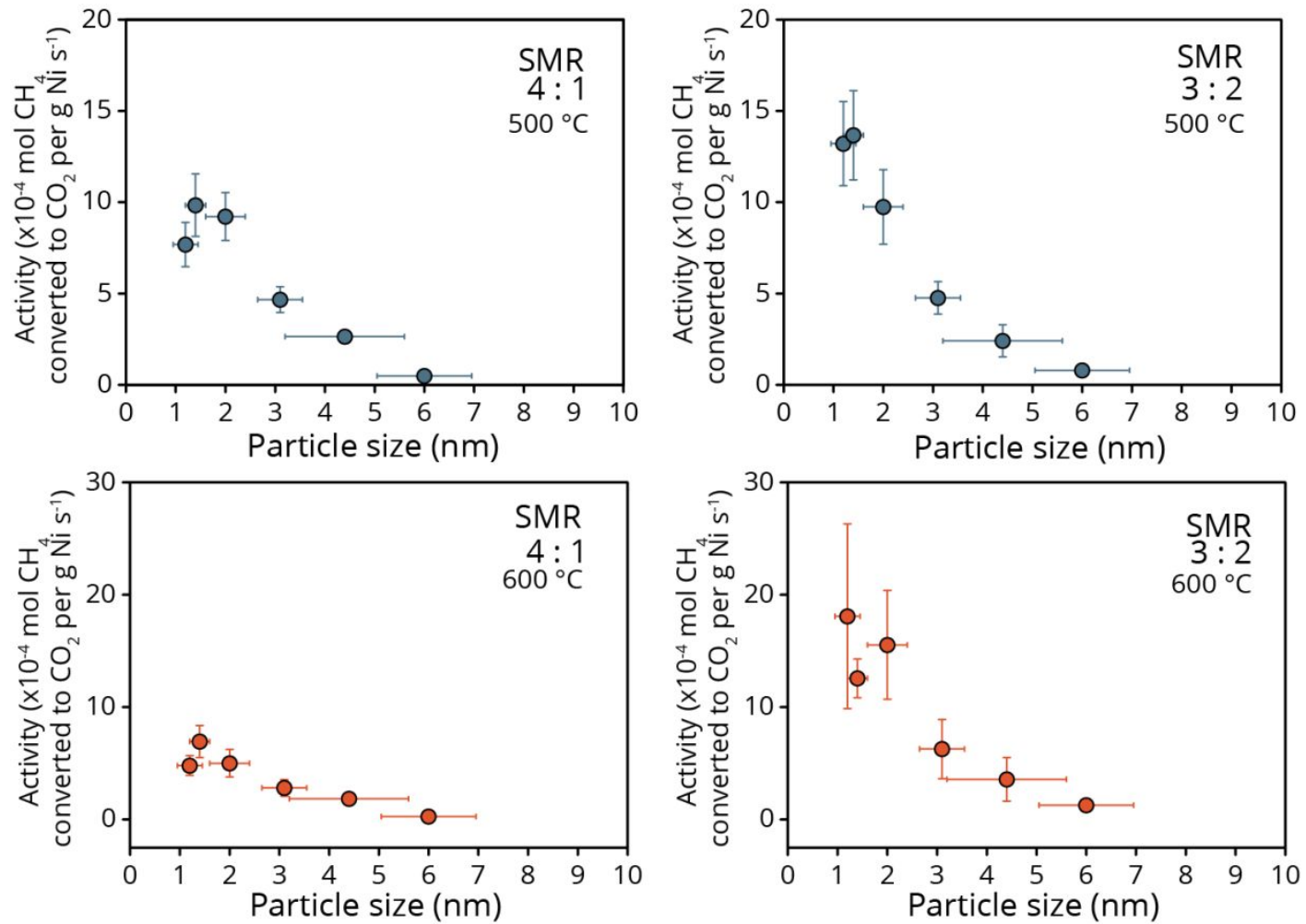

Figure S9. Activity per $\mathrm{g} \mathrm{Ni}$ for $\mathrm{CO}_{2}$ against particle size in steam methane reforming (SMR).
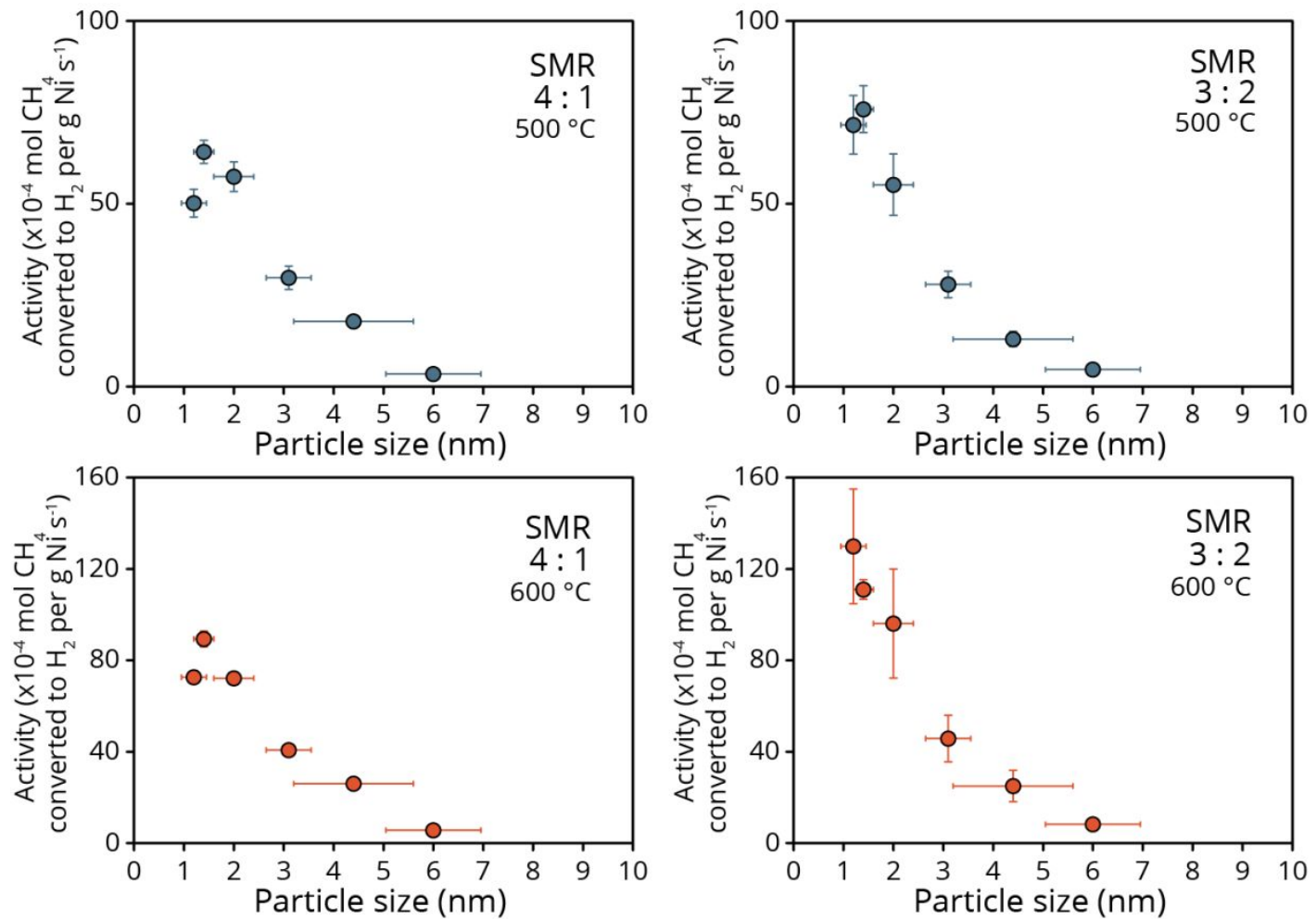

Figure S10. Activity per $\mathrm{g} \mathrm{Ni}$ for $\mathrm{H}_{2}$ against particle size in steam methane reforming (SMR). 

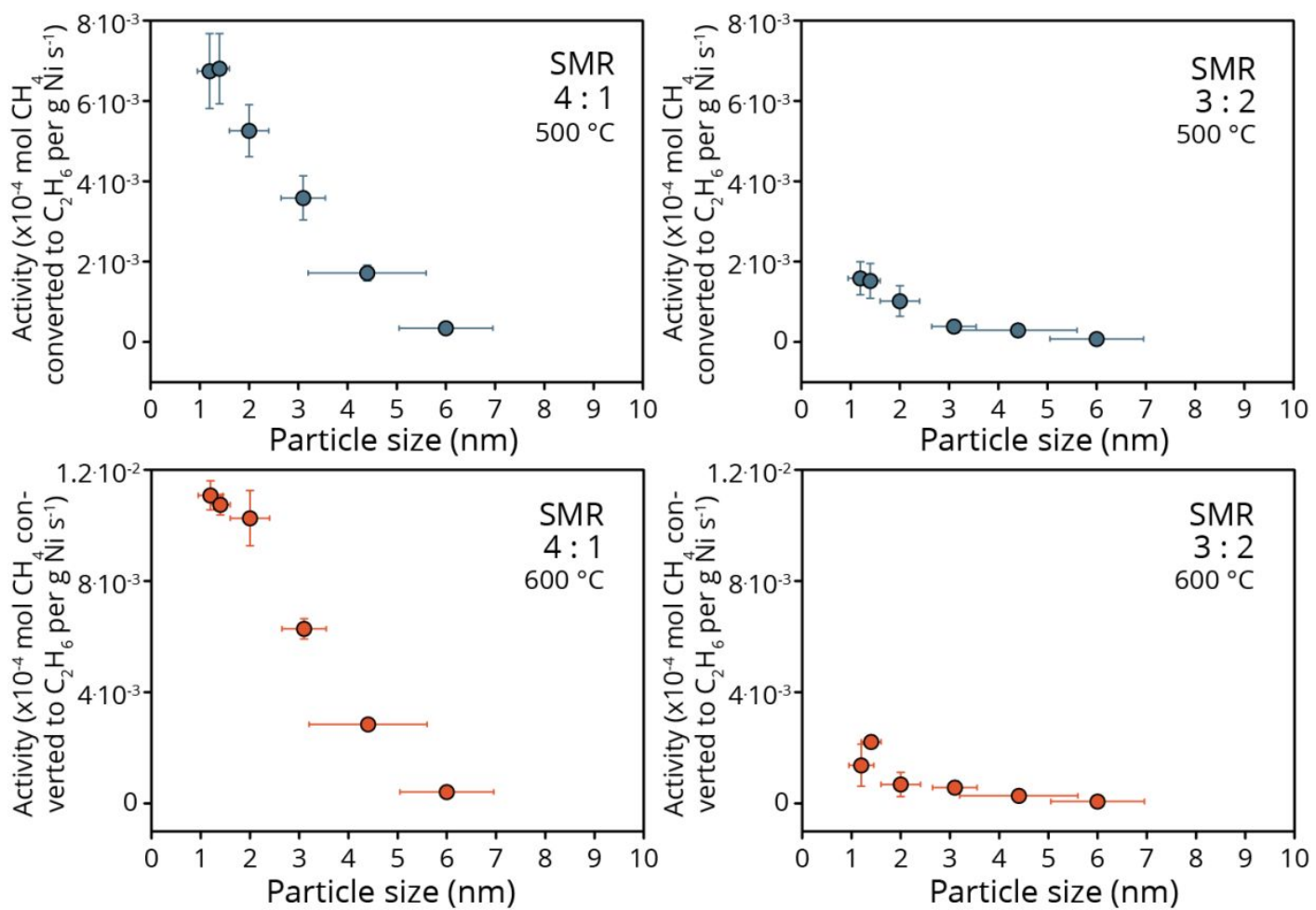

Figure S11. Activity per g Ni towards $\mathrm{C}_{2} \mathrm{H}_{6}$ against particle size in steam methane reforming (SMR). 

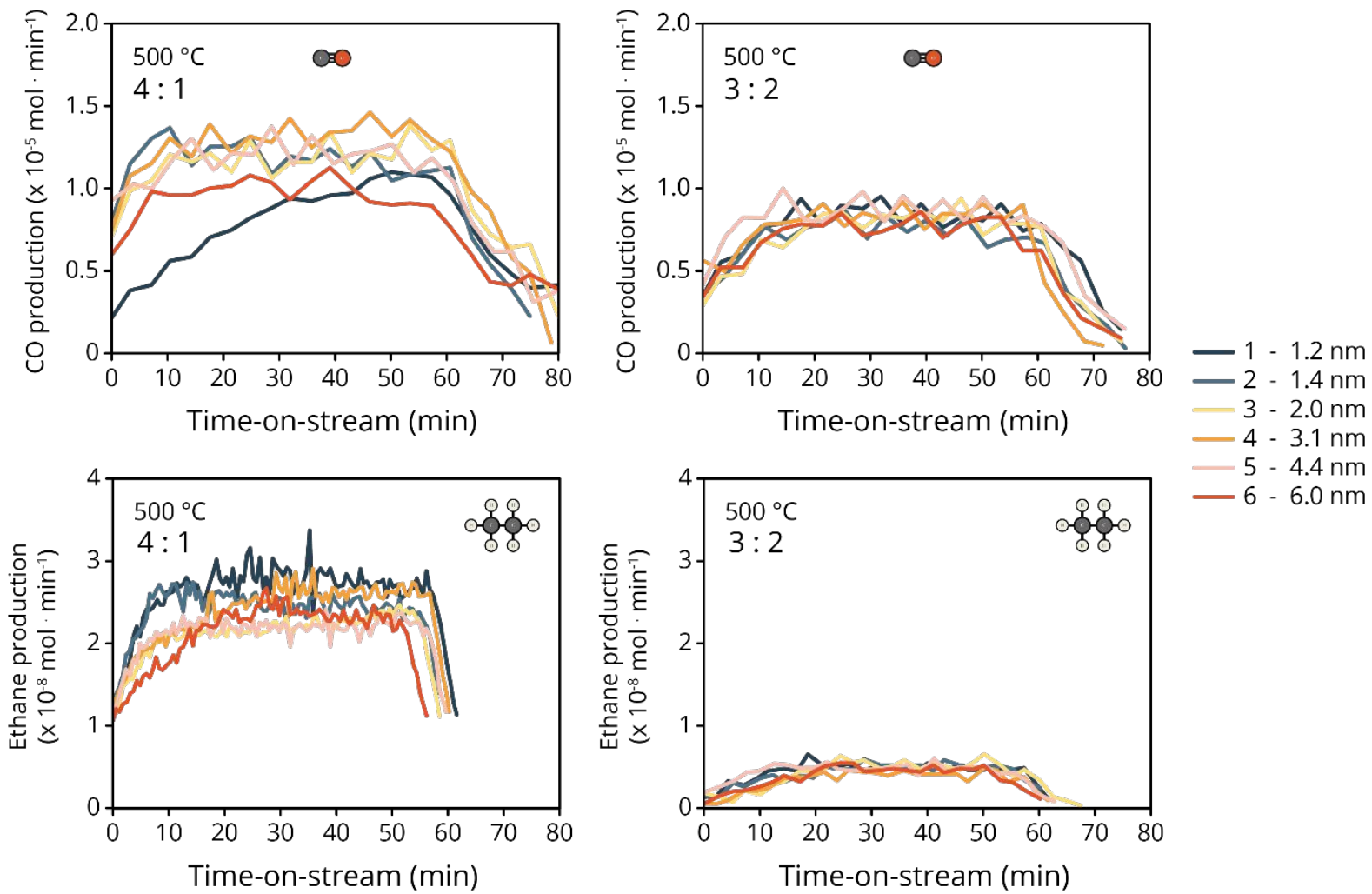

Figure S12. CO and ethane production from gas chromatography against time-on-stream in steam methane reforming (SMR). 


\section{Dry Methane Reforming}

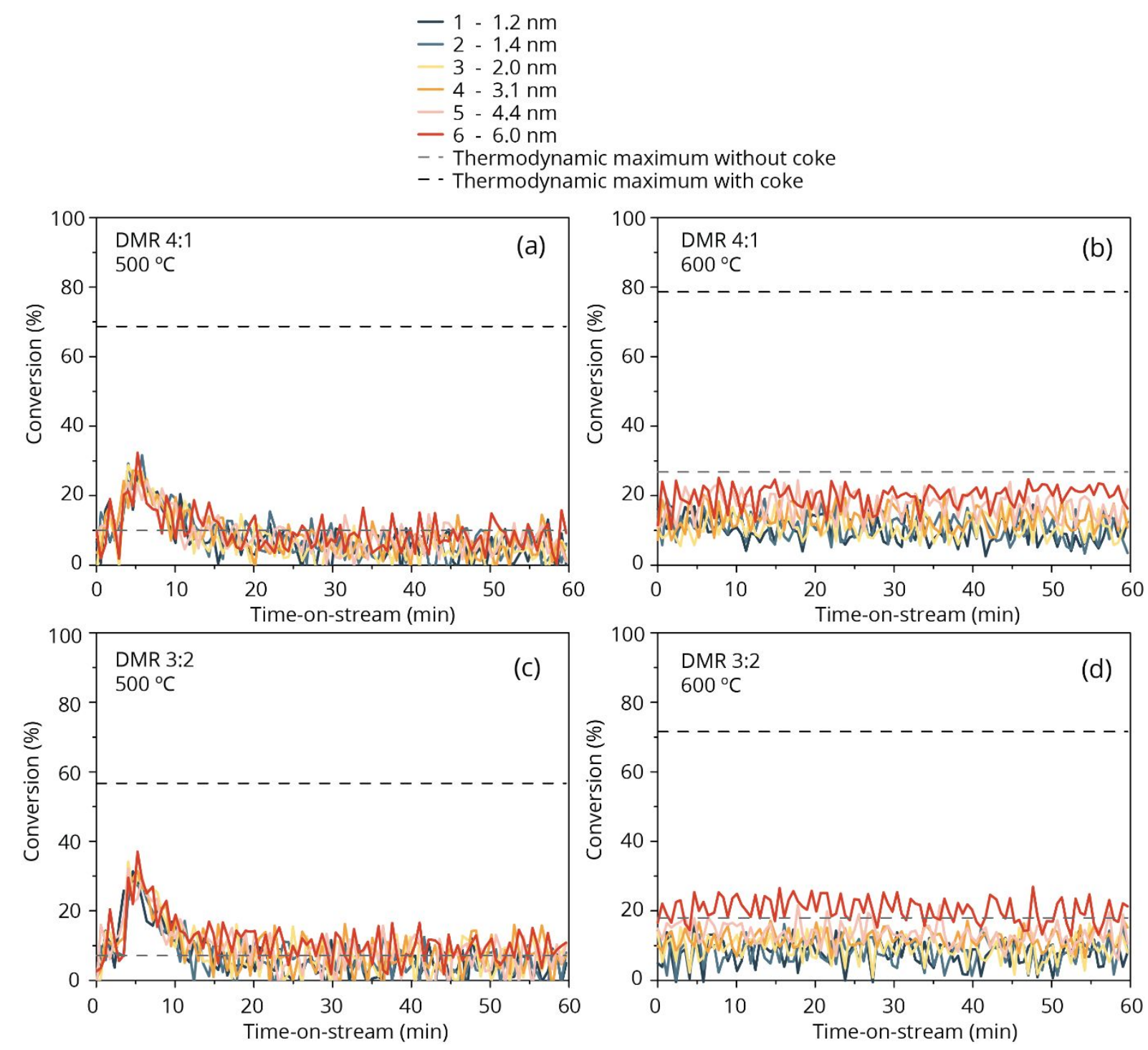

Figure S13. Conversion against time on stream for dry methane reforming (DMR) Ni/SiO 2 catalysts $1-6$, at 500 and $600{ }^{\circ} \mathrm{C}$. and at a feedstock ratio of 4:1 and 3:2 of $\mathrm{CH}_{4}: \mathrm{CO}_{2}$. 

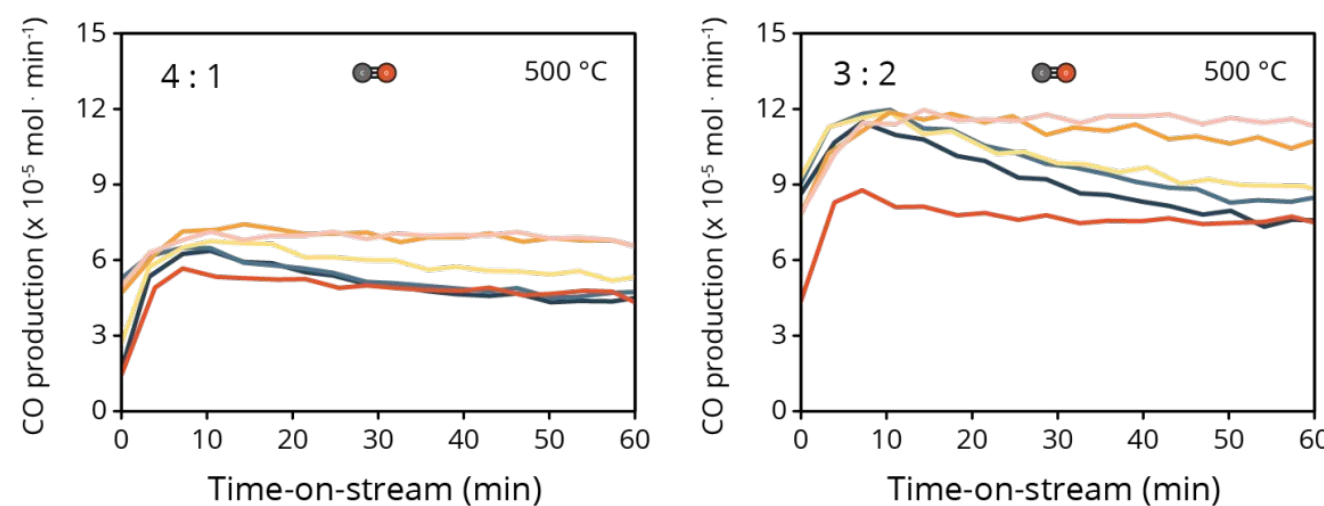

- $1-1.2 \mathrm{~nm}$ $-4-3.1 \mathrm{~nm}$ $-5-4.4 \mathrm{~nm}$
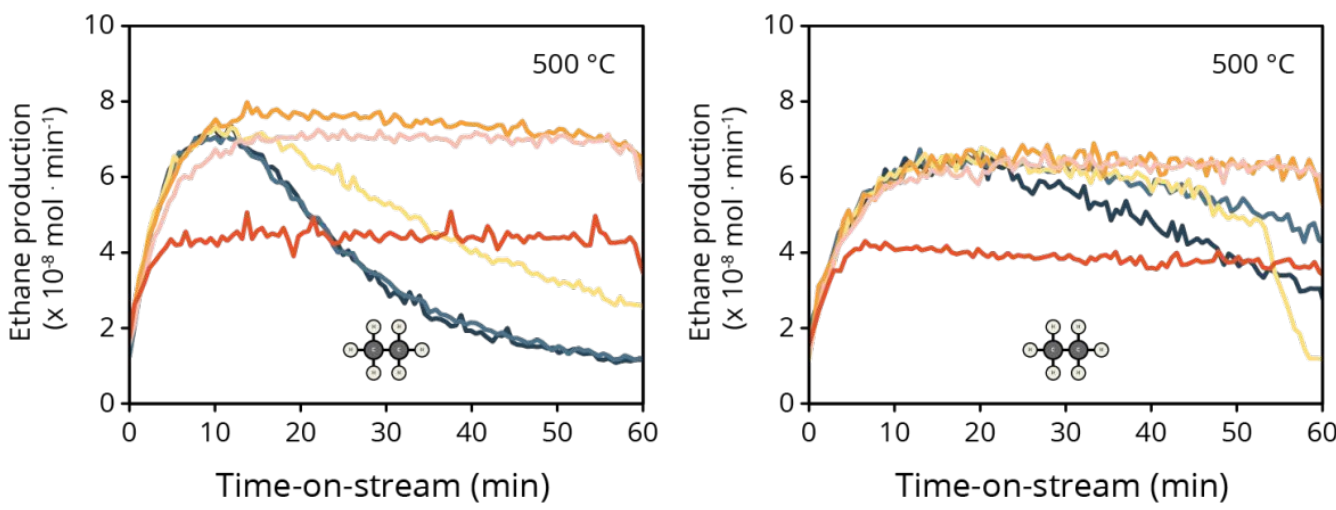

Figure S14. CO and ethane production from gas chromatography against time-on-stream in dry methane reforming (DMR). 


\section{Structure Sensitivity in Literature}
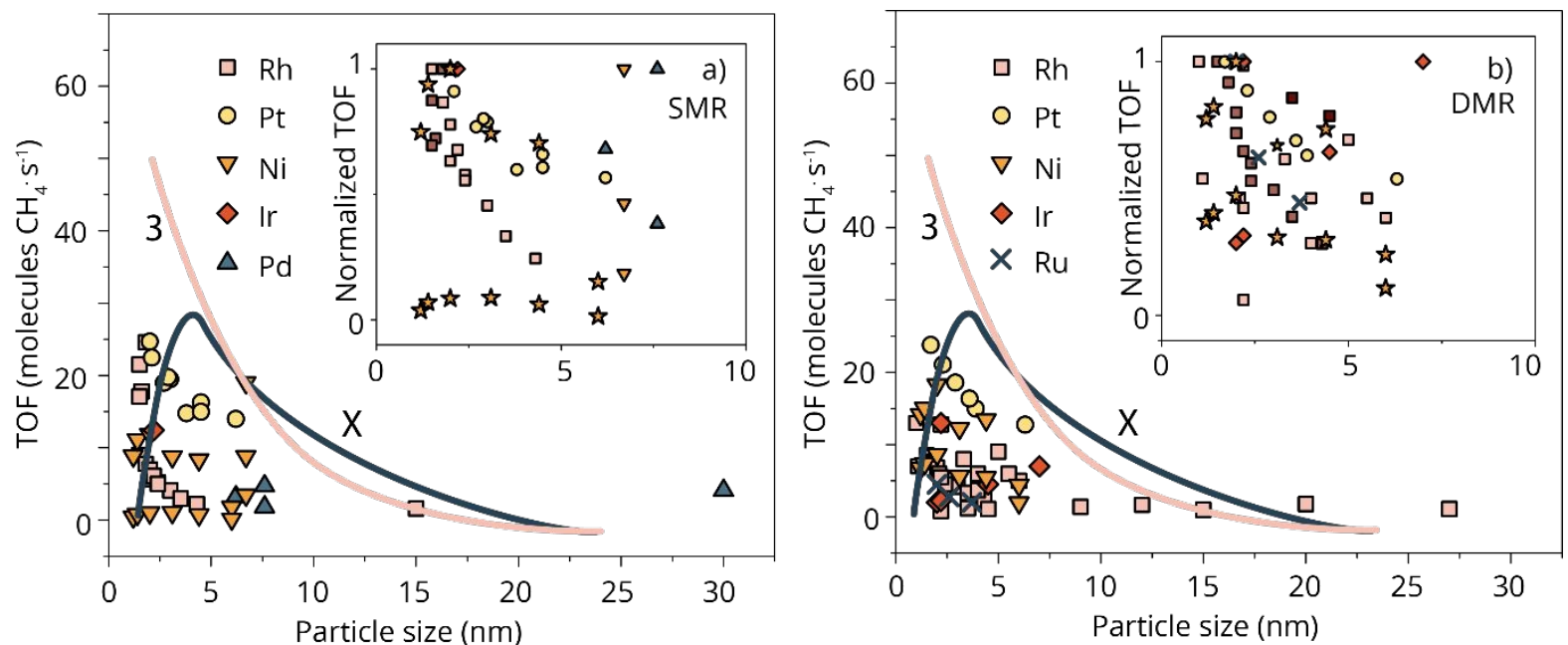

Figure S15. TOF trends as reported in literature for c) steam methane reforming (SMR) and d) dry methane reforming (DMR). The insets represent the TOF trends, normalized per literature work. This figure includes the data reported in this work. The symbols represent the metals, different literature works have different symbol fill color. The lines represent two different types of turnover frequency trends (see Figure 1 of the main text). 


\section{Supplementary Operando FT-IR Spectroscopy Data}

Interestingly, in panel 1 of Figure 4 in the main text, a peak at $3010 \mathrm{~cm}^{-1}$ arises (aside from the peak at $3015 \mathrm{~cm}^{-1}$ ) with increasing Ni metal nanoparticle size. This shoulder is also found for a blank experiment with $\mathrm{SiO}_{2}$, indicating that it is not a reaction intermediate. Rather this surface specie occurs when methane and water are flushed without a catalyst, such as aqueous dissolved methane, $\mathrm{CH}_{4(\mathrm{aq})}{ }^{15}$, and it is also not observed for DMR, which corroborates this spectral assignment. 

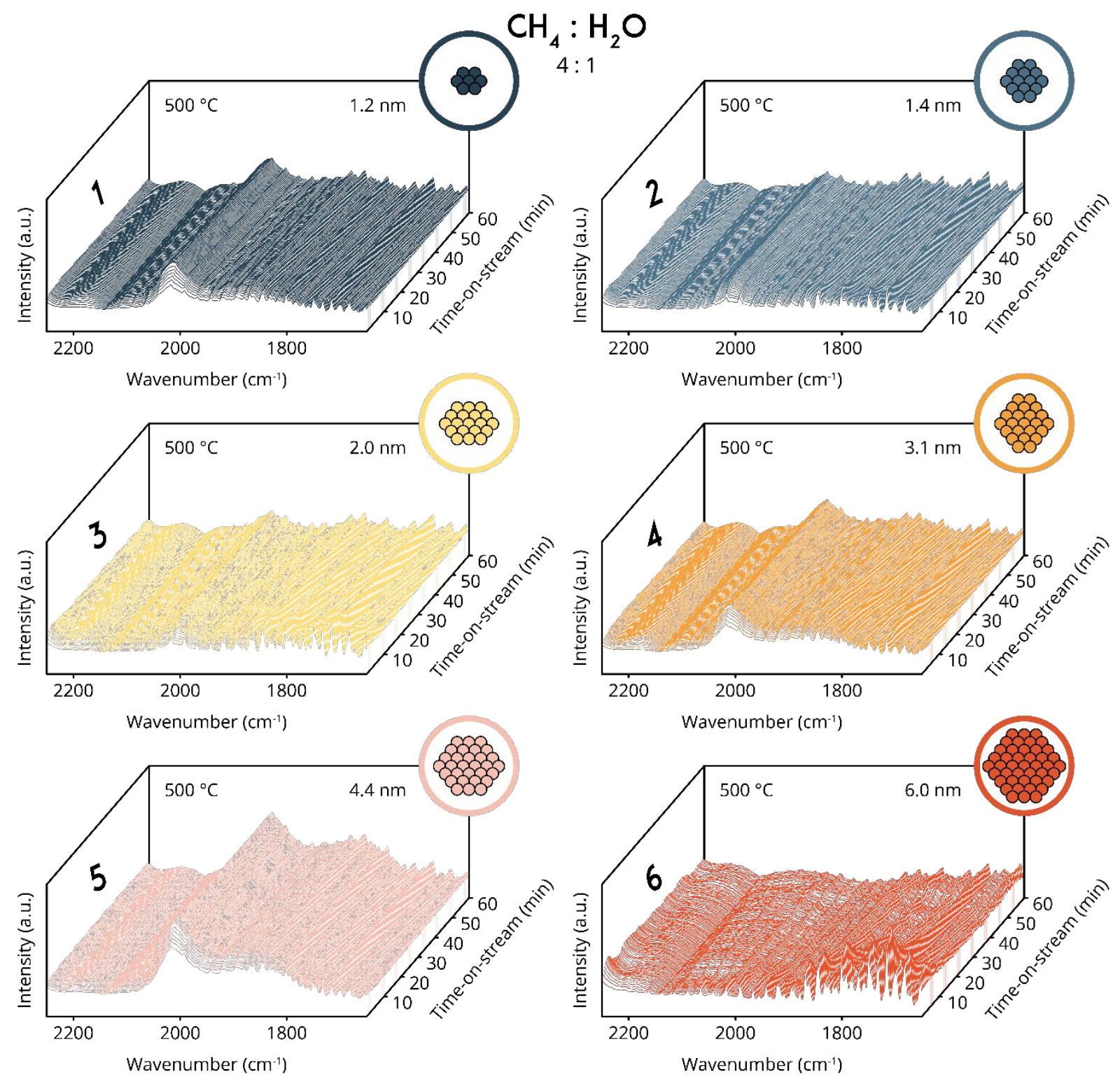

Figure S16. Operando FT-IR spectra for steam methane reforming (SMR) at a $4: 1$ ratio of $\mathrm{CH}_{4}: \mathrm{H}_{2} \mathrm{O}$ at $500{ }^{\circ} \mathrm{C}$ and 5 bar. 

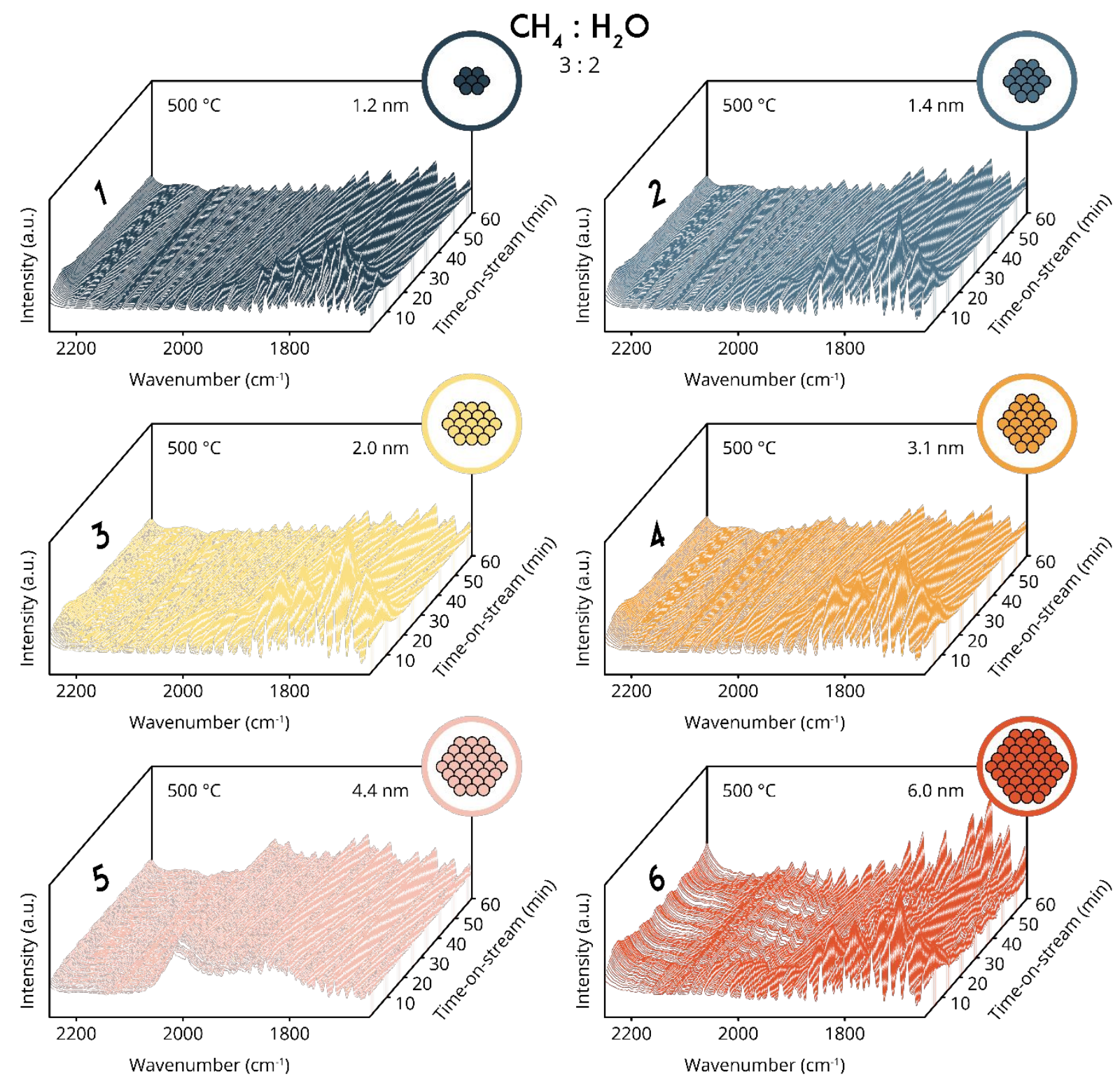

Figure S17. Operando FT-IR spectra for steam methane reforming (SMR) at a $3: 2$ ratio of $\mathrm{CH}_{4}: \mathrm{H}_{2} \mathrm{O}$ at $500{ }^{\circ} \mathrm{C}$ and 5 bar. 

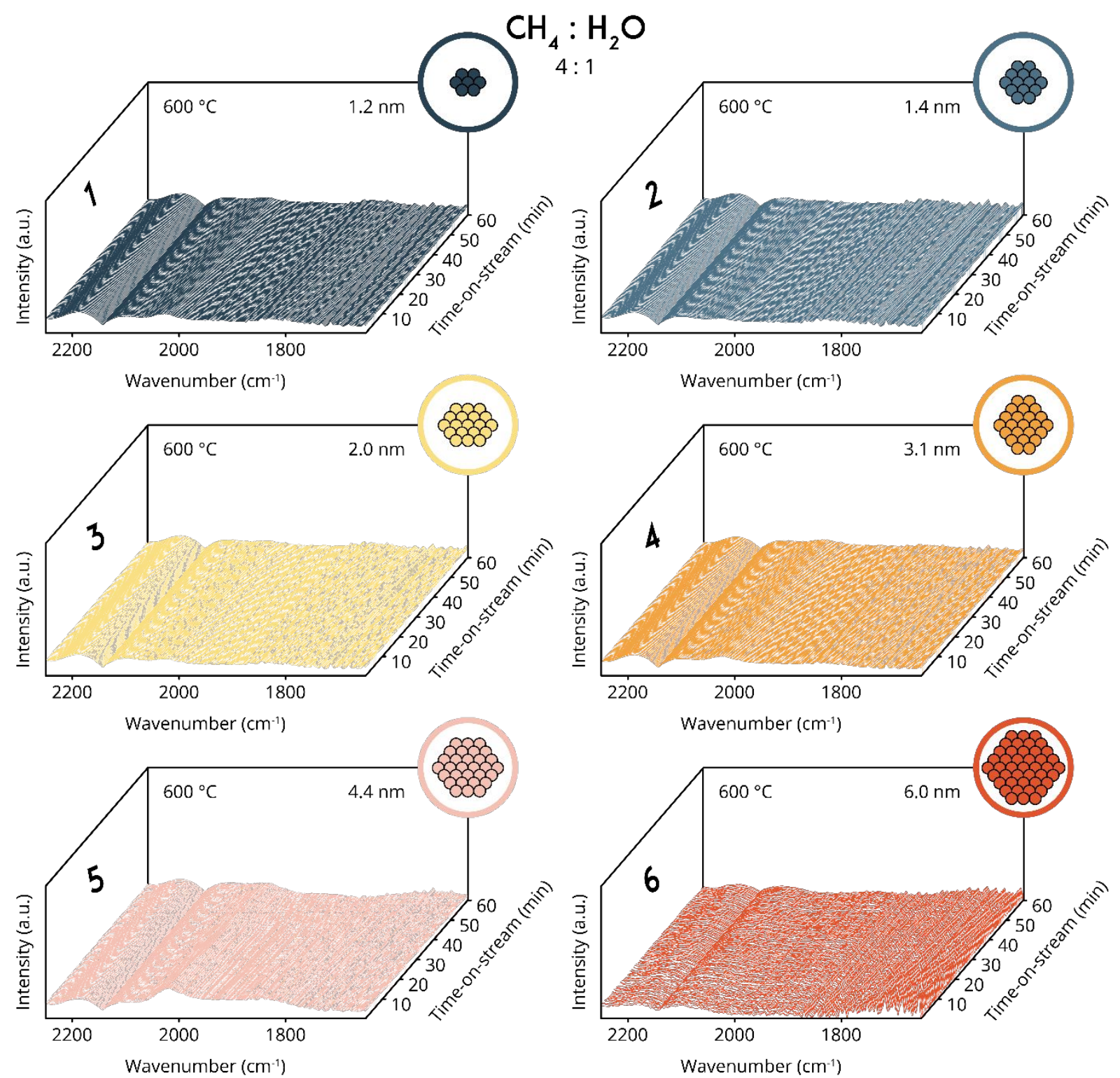

Figure S18. Operando FT-IR spectra for steam methane reforming (SMR) at a $4: 1$ ratio of $\mathrm{CH}_{4}: \mathrm{H}_{2} \mathrm{O}$ at $600{ }^{\circ} \mathrm{C}$ and 5 bar. 

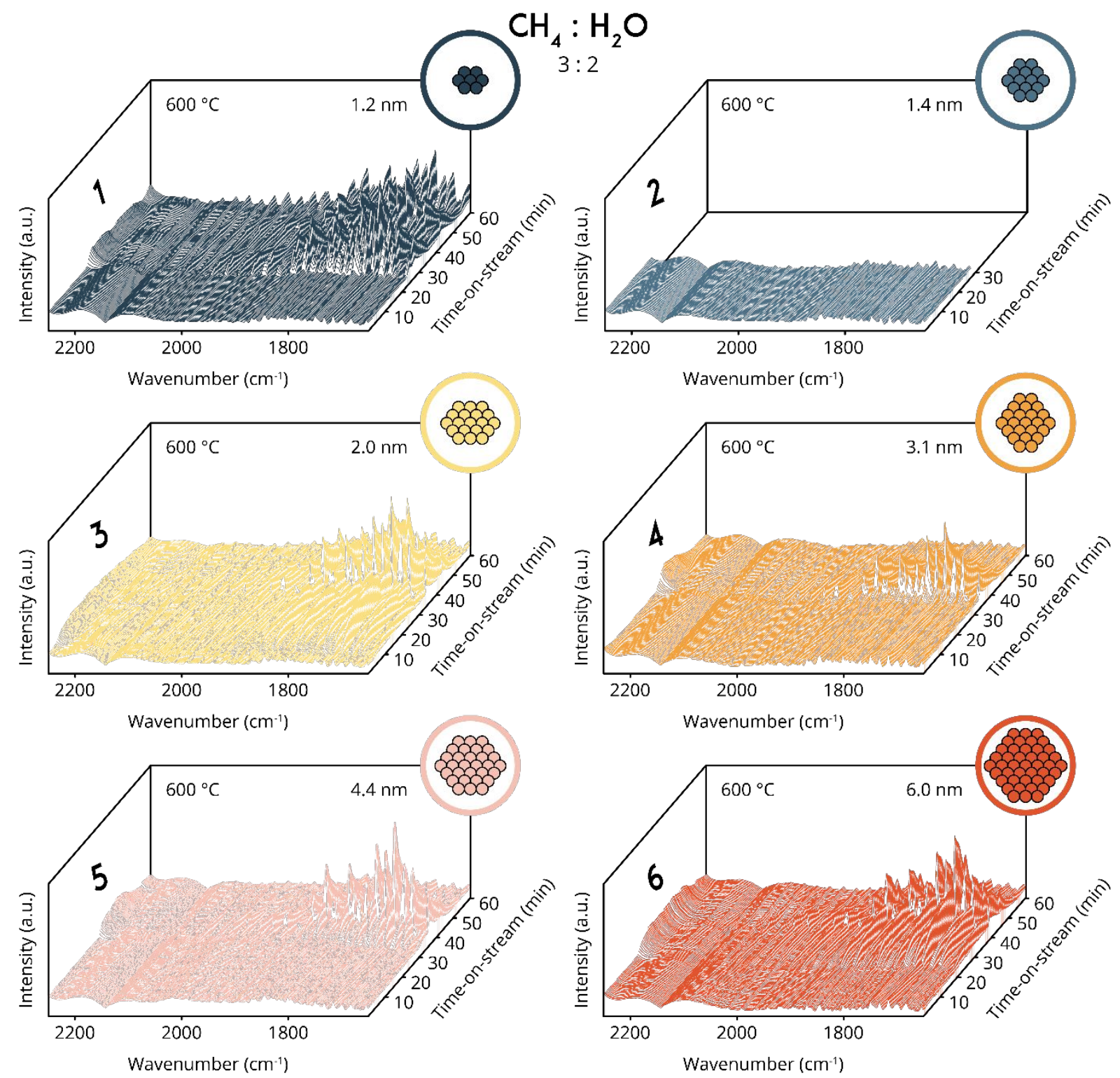

Figure S19. Operando FT-IR spectra for steam methane reforming (SMR) at a 3:2 ratio of $\mathrm{CH}_{4}: \mathrm{H}_{2} \mathrm{O}$ at $600{ }^{\circ} \mathrm{C}$ and 5 bar. 

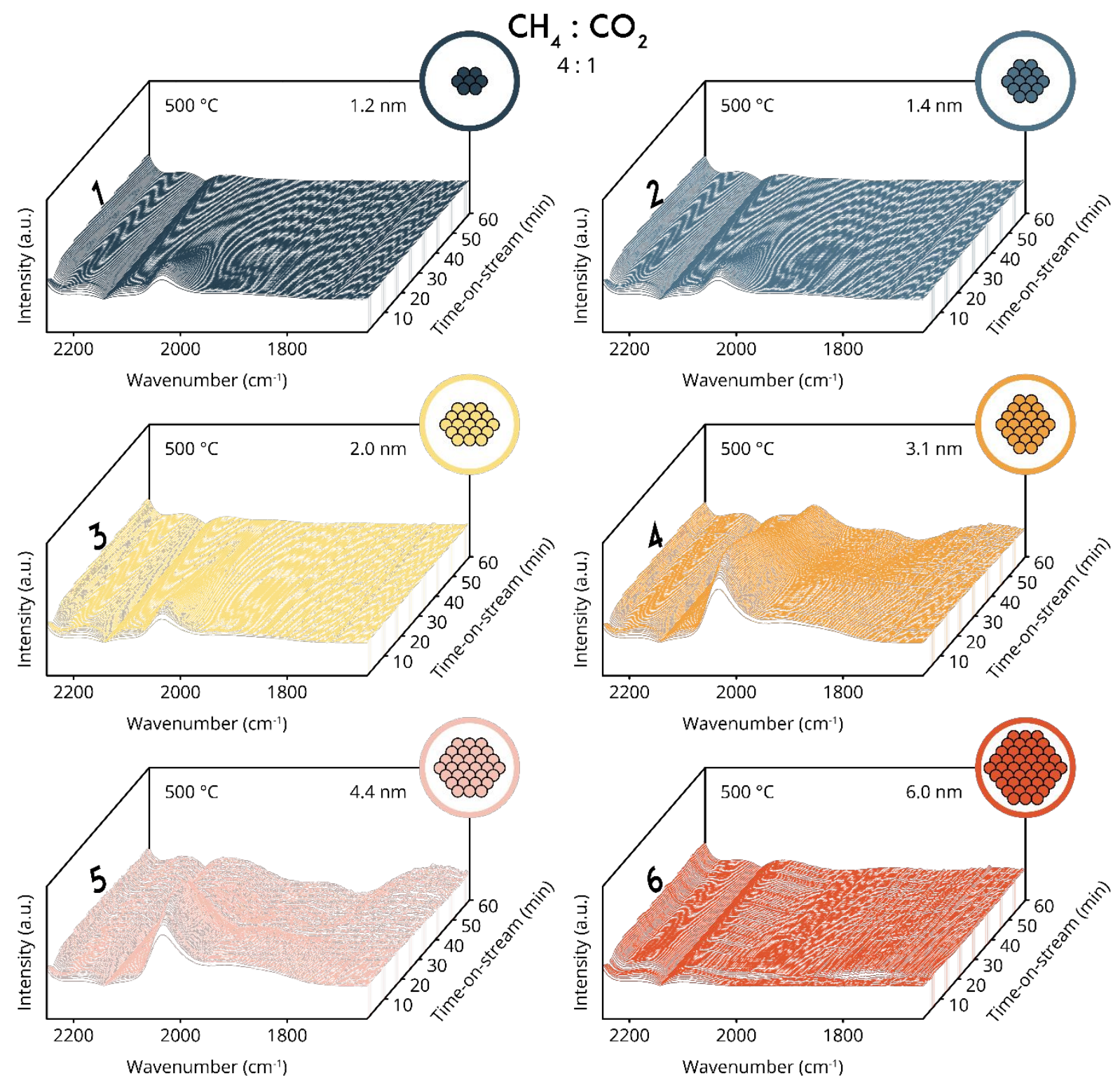

Figure S20. Operando FT-IR spectra for dry methane reforming (DMR) at a $4: 1$ ratio of $\mathrm{CH}_{4}: \mathrm{CO}_{2}$ at $500{ }^{\circ} \mathrm{C}$ and 5 bar. 

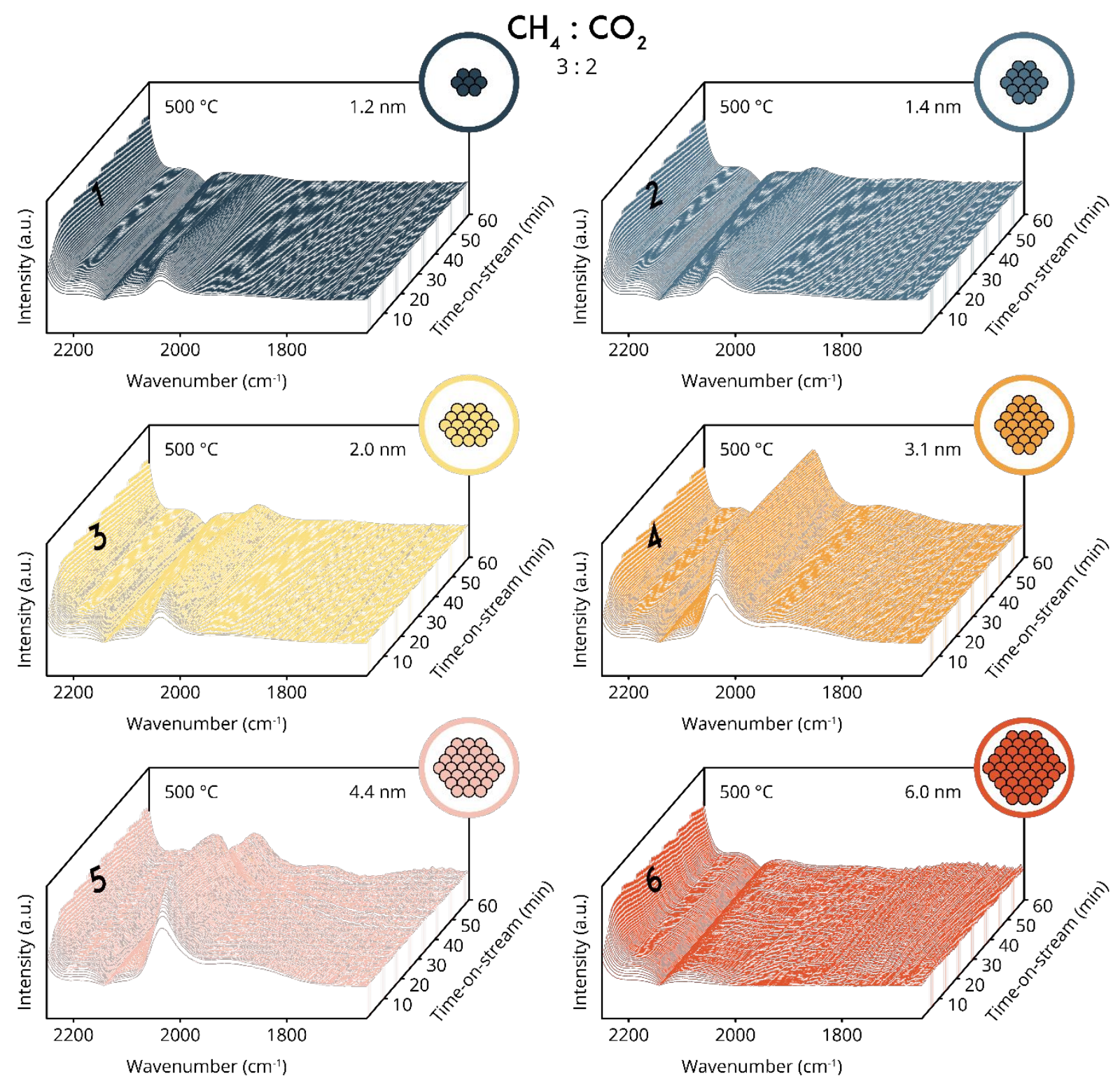

Figure S21. Operando FT-IR spectra for dry methane reforming (DMR) at a 3:2 ratio of $\mathrm{CH}_{4}: \mathrm{CO}_{2}$ at $500{ }^{\circ} \mathrm{C}$ and 5 bar. 

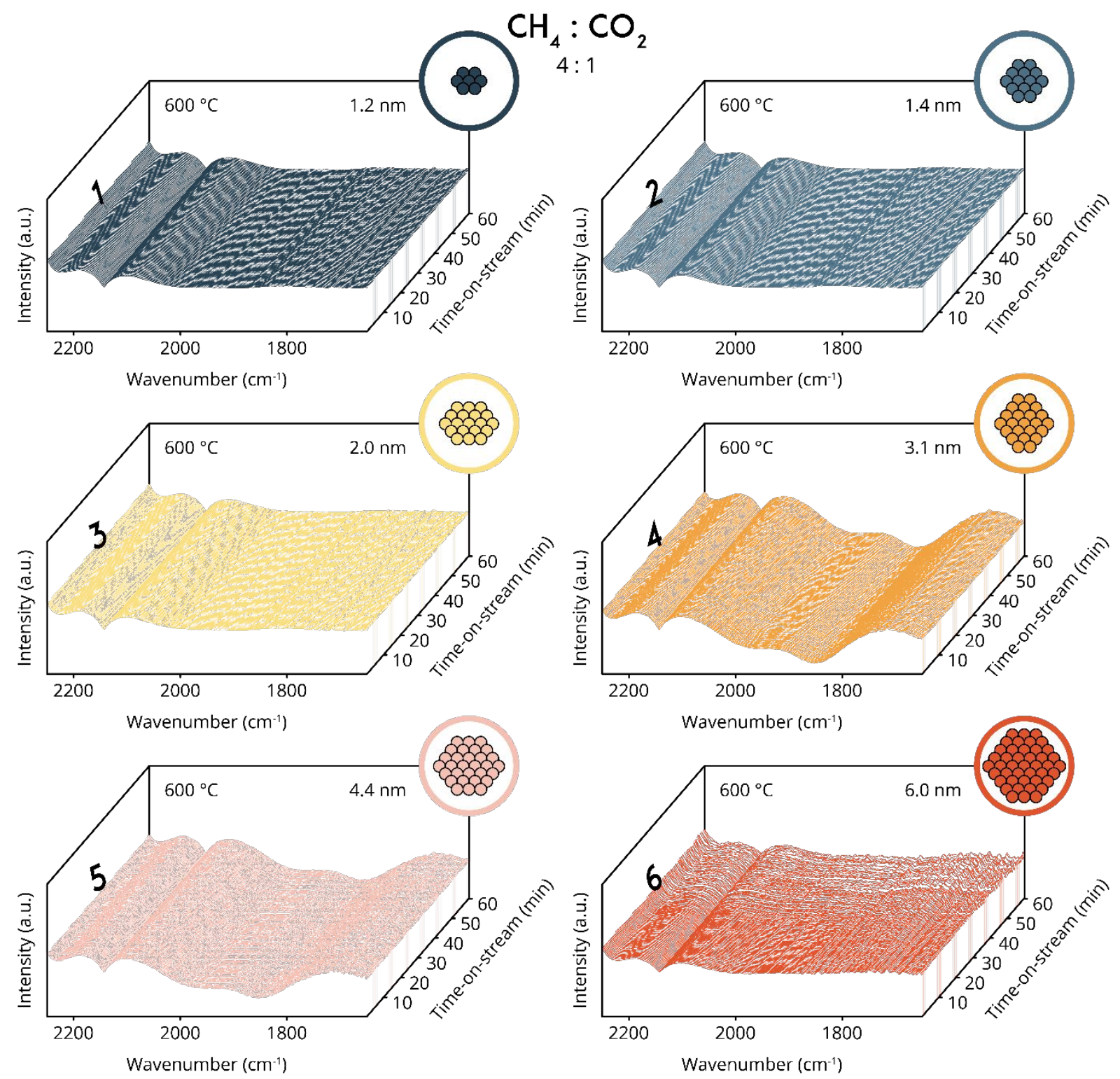

Figure S22. Operando FT-IR spectra for dry methane reforming (DMR) at a $4: 1$ ratio of $\mathrm{CH}_{4}: \mathrm{CO}_{2}$ at $600{ }^{\circ} \mathrm{C}$ and 5 bar. 

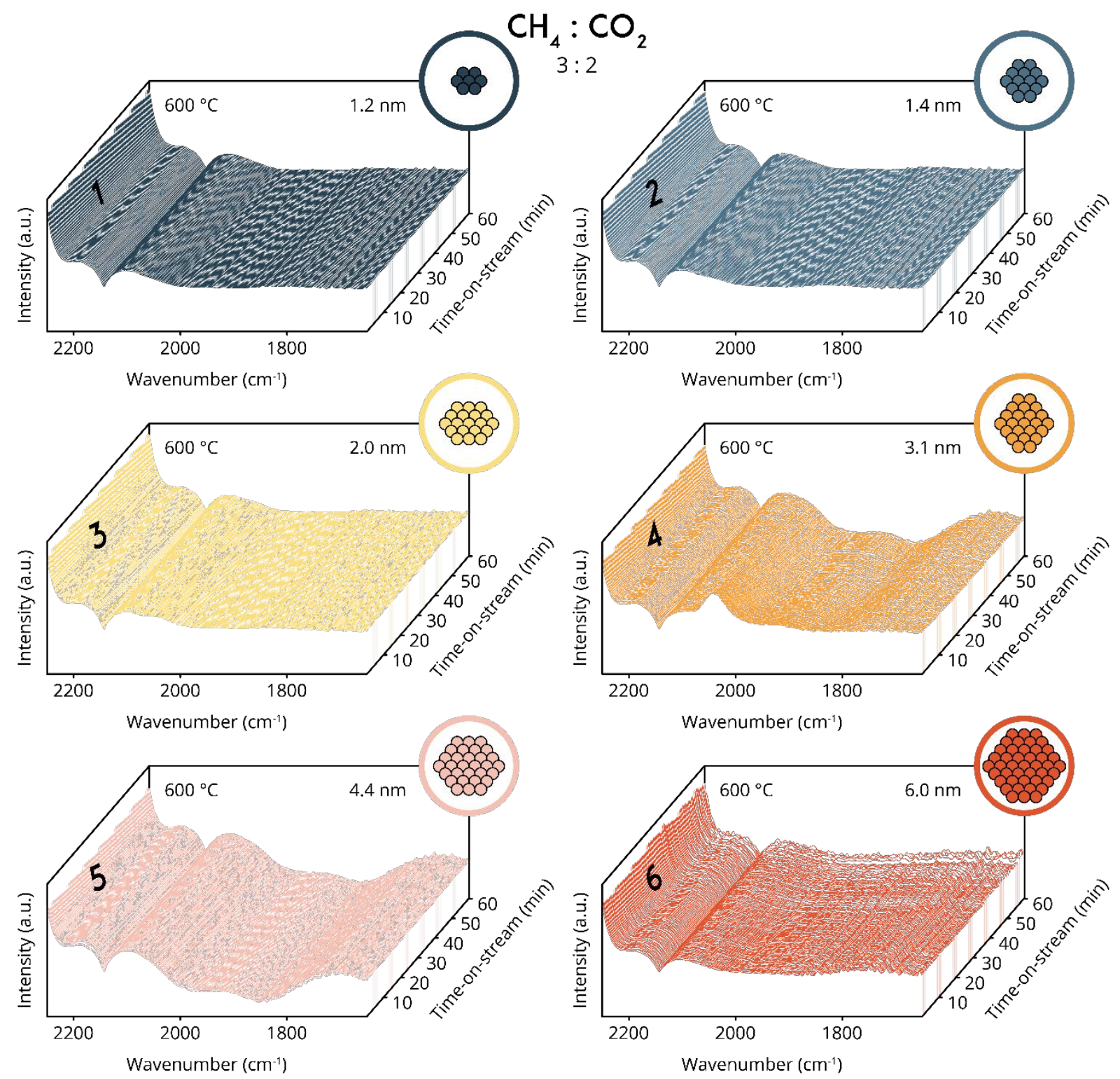

Figure S23. Operando FT-IR spectra for dry methane reforming (DMR) at a 3:2 ratio of $\mathrm{CH}_{4}: \mathrm{CO}_{2}$ at $600{ }^{\circ} \mathrm{C}$ and 5 bar. 

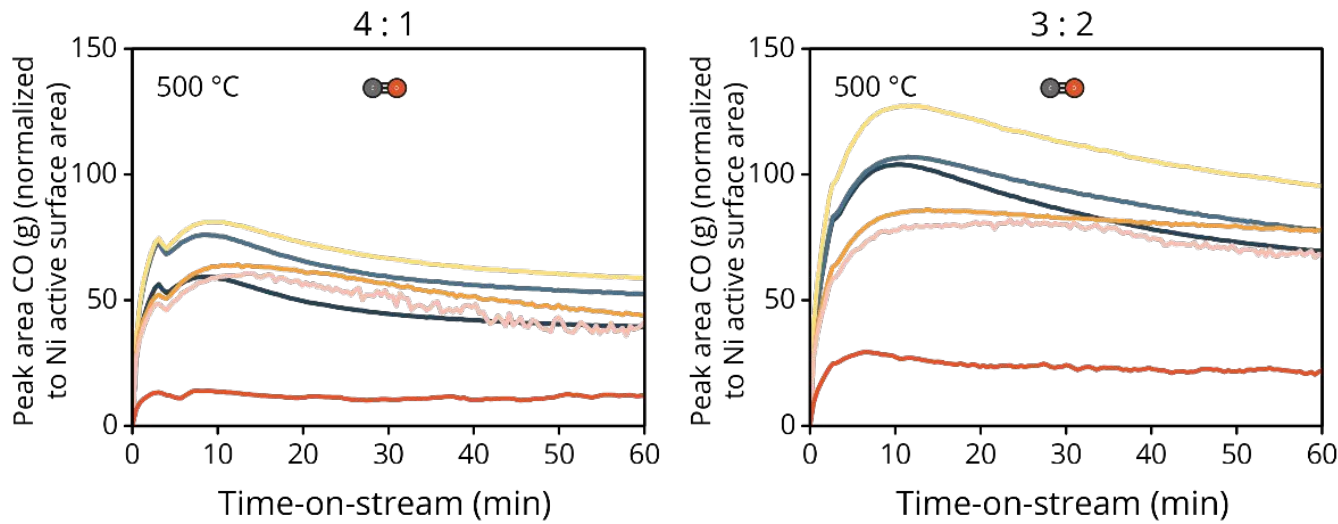

$-1-1.2 \mathrm{~nm}$

$-2-1.4 \mathrm{~nm}$

$3-2.0 \mathrm{~nm}$

$-4-3.1 \mathrm{~nm}$

$-5-4.4 \mathrm{~nm}$

$-6-6.0 \mathrm{~nm}$

Figure S24. Dry methane reforming, peak integrations for gaseous CO plotted against time-on-stream. 


\section{Carbon Formation}

Thermogravimetric analysis (TGA) has been performed on all spent catalyst samples with the purpose of obtaining information on carbon deposition and whether the Ni mean particle size has an influence on carbon deposition and active site blocking. For each spent catalyst sample, two cycles of thermogravimetric measurements have been executed. First, the sample was held at $30{ }^{\circ} \mathrm{C}$ for 10 minutes, followed by heating to $900{ }^{\circ} \mathrm{C}$ with a ramp of $5{ }^{\circ} \mathrm{C} \cdot \mathrm{min}^{-1}$. It was kept at $900{ }^{\circ} \mathrm{C}$ for $1 \mathrm{~min}$ and after that the sample cooled down to $30^{\circ} \mathrm{C}$ with a ramp of $50{ }^{\circ} \mathrm{C} \cdot \mathrm{min}^{-1}$. It was held at $30^{\circ} \mathrm{C}$ for $45 \mathrm{~min}$ and afterwards, followed by again ramping to $900{ }^{\circ} \mathrm{C}$ with a ramp of $5{ }^{\circ} \mathrm{C} \cdot \mathrm{min}^{-1}$. Here, it was kept there for $1 \mathrm{~min}$ before cooling down to room temperature.

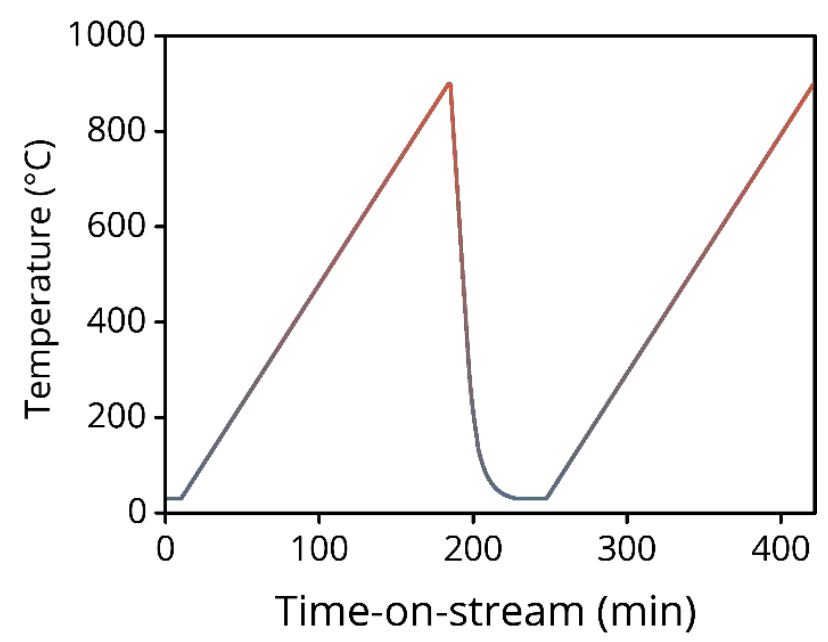

Figure S25. Temperature program applied for TGA measurements.

In Figure S25 the relative residual mass is plotted against time-on-stream. Here, a first indication towards carbon formation is shown. For both ratios, catalyst 1-4 show a relative low decrease in relative residual mass which indicates that almost no carbon formation was formed during SMR for these catalysts regardless of the ratio used between reactants. On the other hand, catalyst 5 and 6 (ratio 4:1) show a larger decrease in relative residual mass, which suggests that carbon deposition has occurred for these larger Ni nanoparticles. 

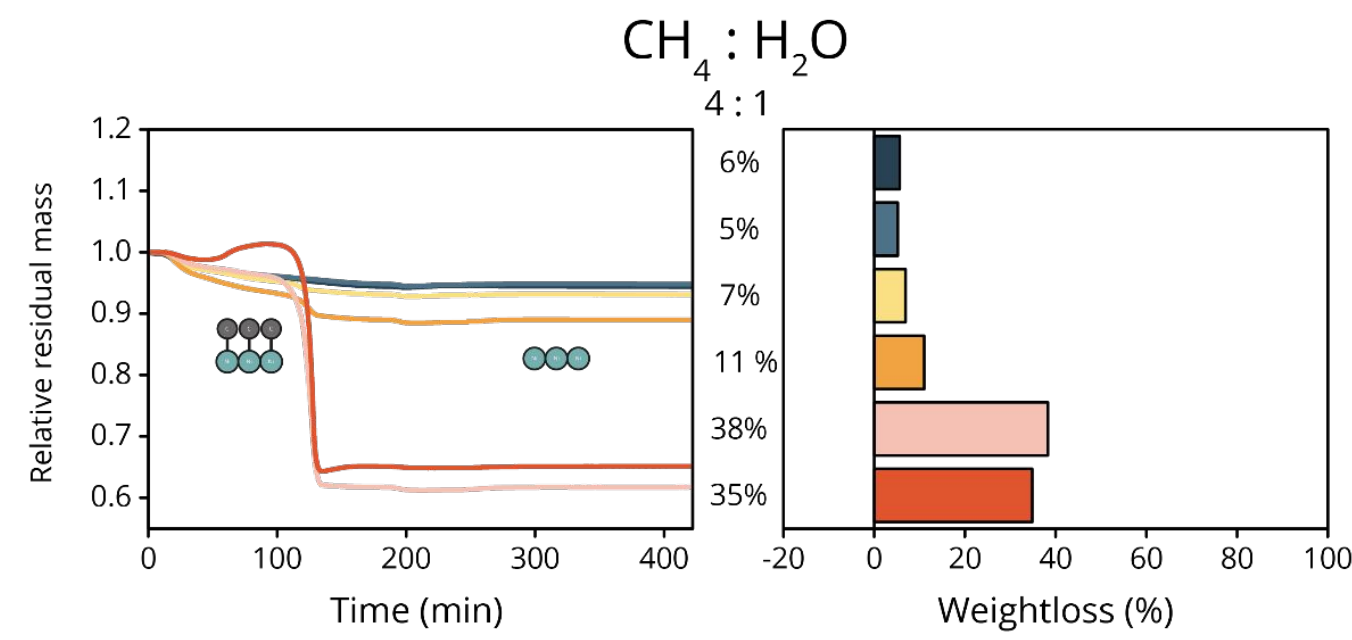

$1-1.2 \mathrm{~nm}$
$-2-1.4 \mathrm{~nm}$
$-3-2.0 \mathrm{~nm}$
$4-3.1 \mathrm{~nm}$
$5-4.4 \mathrm{~nm}$
$-6-6.0 \mathrm{~nm}$
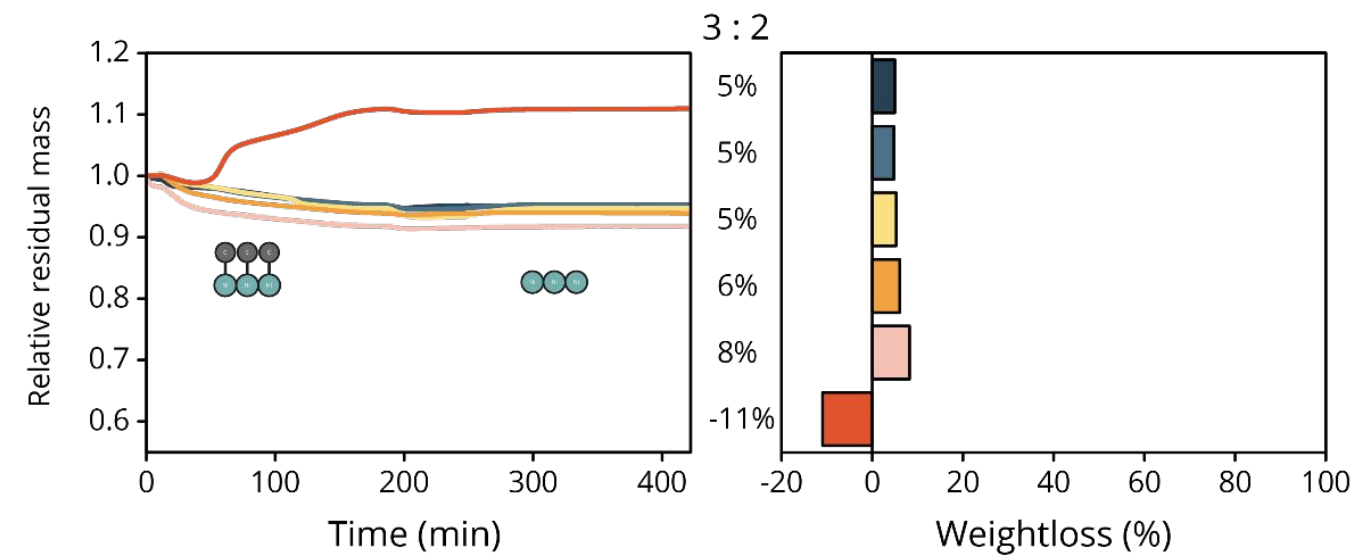

Figure S26. Left: Residual weight fraction plotted against time-on-stream for both ratios of reactants. Right: Percentage weight loss for each catalyst for steam methane reforming (SMR). 


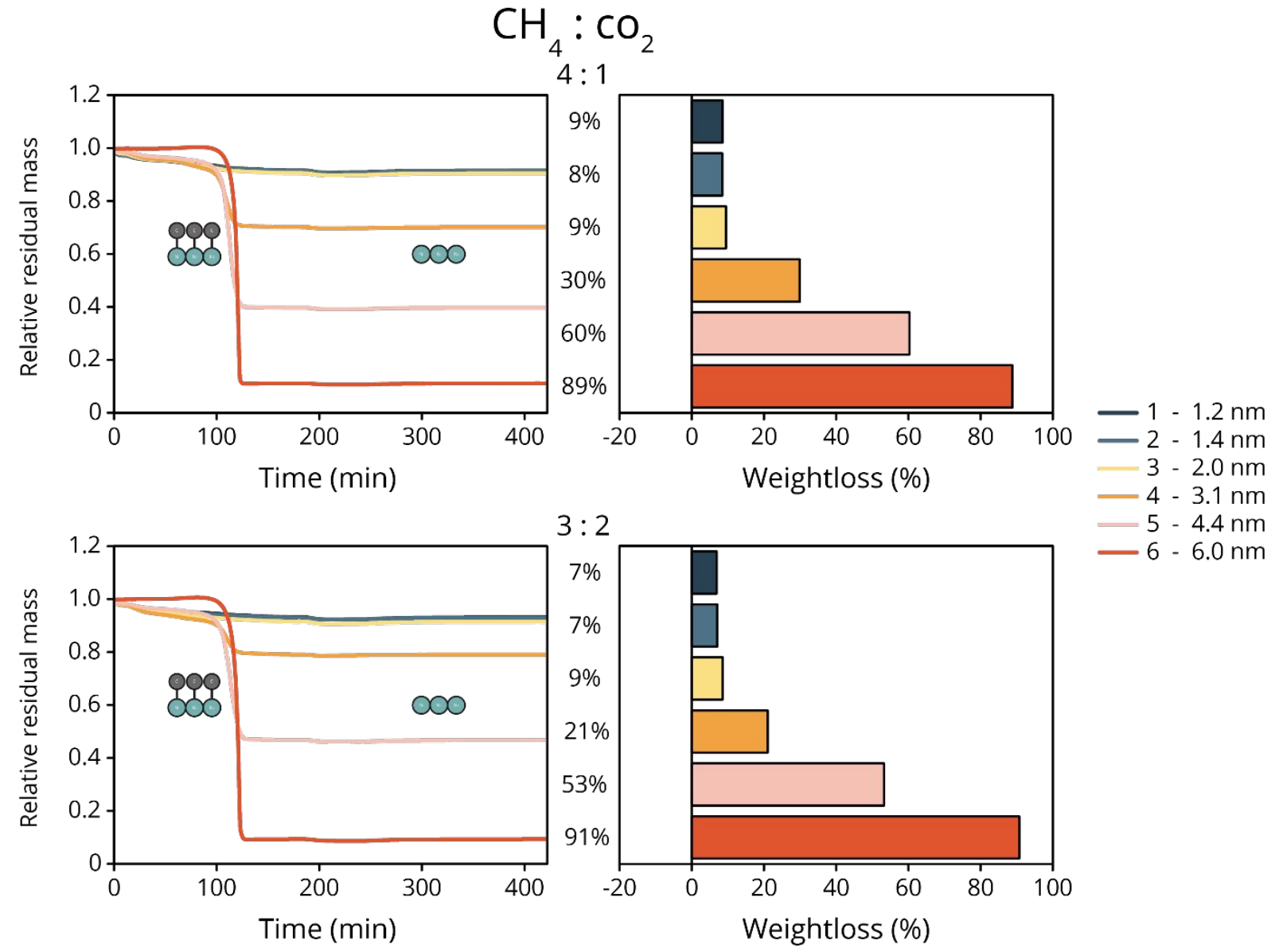

Figure S27. Left: Residual weight fraction plotted against time-on-stream for both ratios of reactants. Right: Percentage weight loss for each catalyst for dry methane reforming (DMR). 

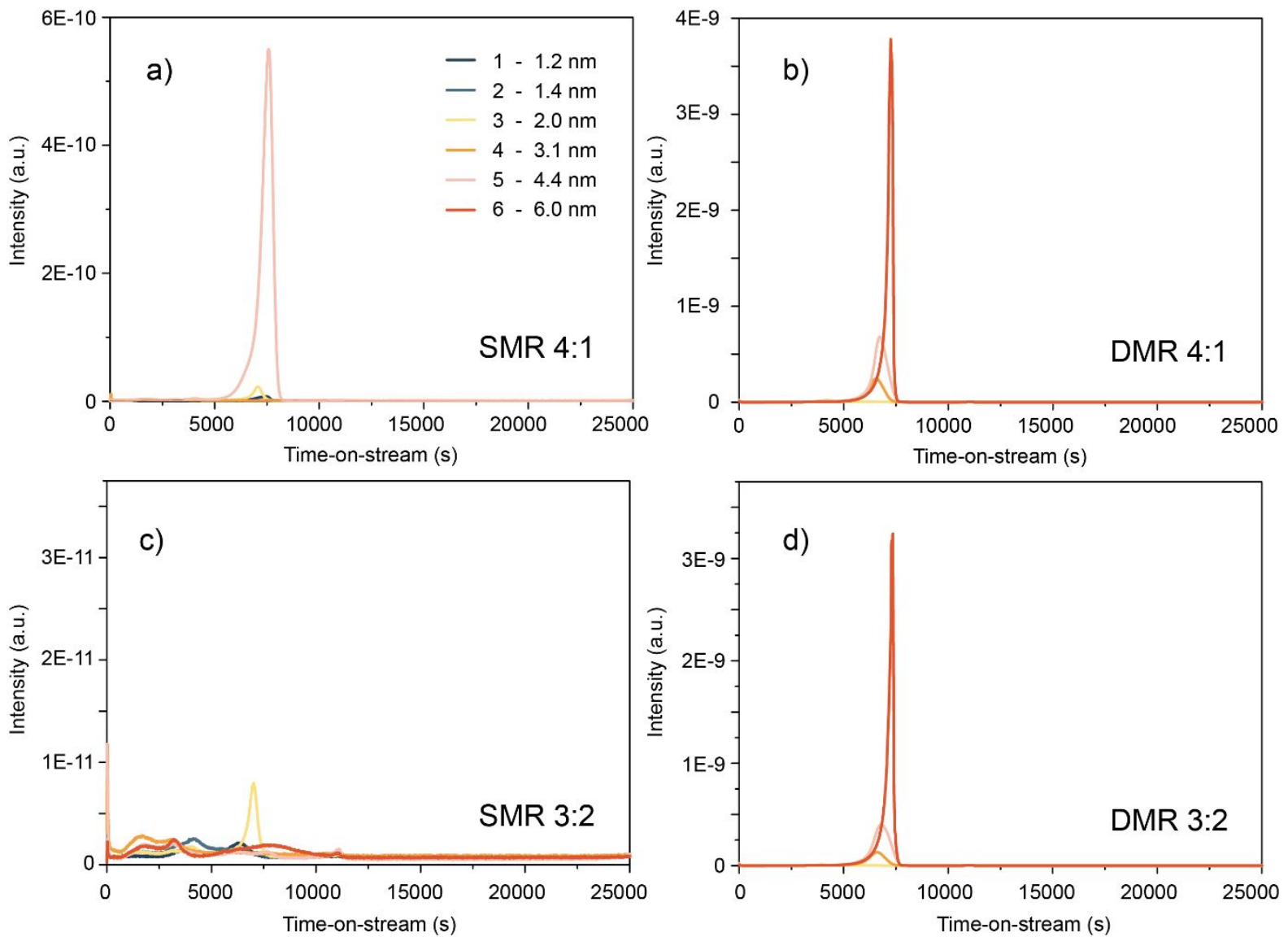

Figure S28. Mass spectrometry profiles of the mass for carbon dioxide (44) as measured during thermogravimetric analysis of the spent catalyst samples 1-6 in SMR and DMR at feedstock ratios of 3:2 and 4:1 of $\mathrm{CH}_{4}: \mathrm{H}_{2} \mathrm{O} / \mathrm{CO}_{2}$. 


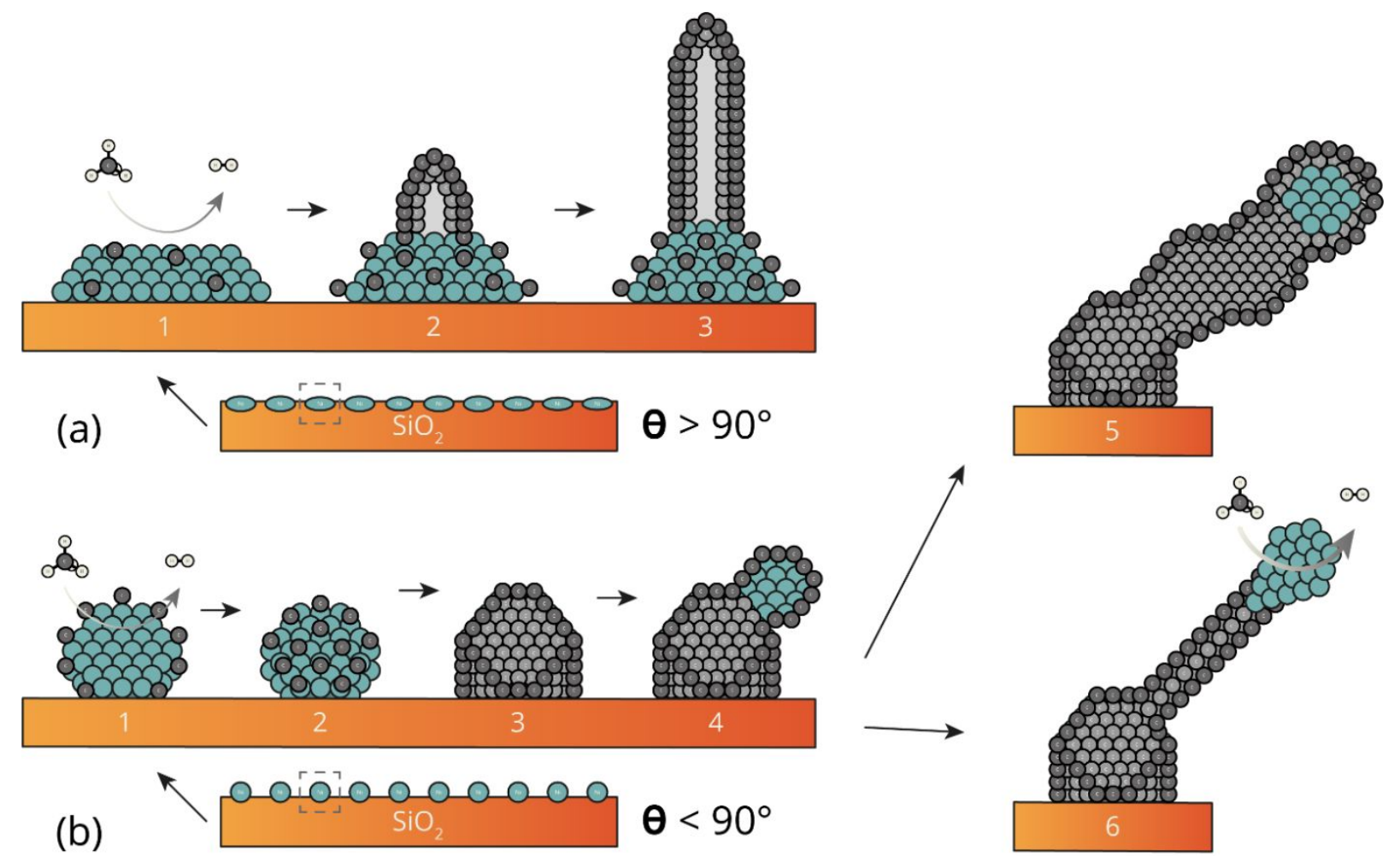

Figure S29. Schematic showing the possible mechanisms for carbon fiber formation, depending on the degree of metalsupport interaction, which in turn depends on NPs size.

Whisker carbon formation is common in methane reforming. These carbon whiskers have high mechanical strength and can cause the catalyst to break ${ }^{16}$. Depending on the size of the metal nanoparticles, the metal-support interaction changes, different growth mechanisms for carbon whiskers can occur ${ }^{17}$. Figure 8 a shows the mechanism known as the base-growth model where the metal-support interaction is strong (nanoparticle-support contact angle $>90^{\circ}$ ) ${ }^{18}$. Figure $8 \mathrm{~b}$ shows the mechanism for the tip-growth model, where the metal-support interaction is weak (nanoparticle-support contact angle $<90^{\circ}$ ). The strength of this interaction determines whether the metal nanoparticle is ejected or not. For weak interactions the carbon nanotube grows at the bottom part of the ejected nanoparticle. For strong interactions the carbon nanofiber grows at the top of the metal nanoparticle, which still has interaction with the support. Generally speaking, the smaller the nanocluster, the stronger its interaction with the support. For the nucleation of carbon nanofibers based on the tip-growth model the metal nanoparticle is pushed out as a result of tension buildup due the formation of graphite layers (step 4 in Figure 8). The adsorbed carbon atoms form carbon fibers on the bottom side of the Ni nanoparticle. By doing so, the whisker will lift the Ni nanoparticle to its tip. This ultimately changes the Ni nanoparticle shape from spherical to pear-shaped. Small Ni-fragments may be left behind in the whisker. Once a Ni cluster is pressed out, the fresh surface (of which the morphology has changed) is exposed to the reactants again 
and nanofibers start to grow (step 5 and 6). An important property of these pear-shaped Ni crystals with fibers, is that the Ni surface is thus not deactivated.

For catalysts 1-3 the relative amount of carbon deposited is similar for both reactant ratios tested (Figure 7). For the larger catalyst samples 5 and 6, one could assume some surface to have become inaccessible either to sintering or to coverage by carbon. In this case the active surface area will become smaller, and the TOF consequently higher. With growth maximal growth of a factor 4 observed in TEM, the TOF trend with a maximum, which is observed and explained in the main text would in all cases remain similar. 

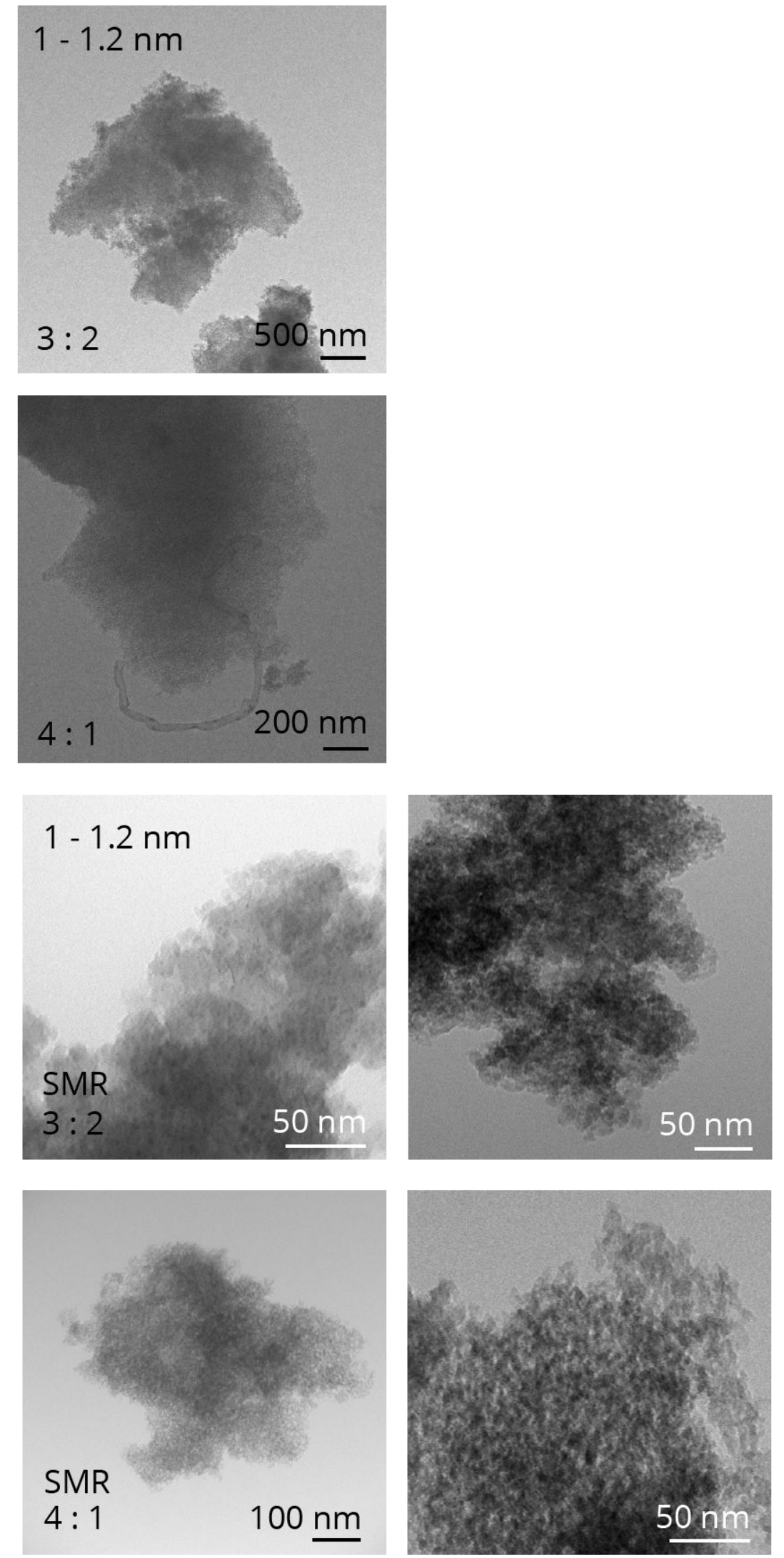

Figure S30. Representative transmission electron microscopy micrographs for $\mathrm{SiO}_{2}$ supported $\mathrm{Ni}$ catalyst sample 1 for dry methane reforming (DMR) and steam methane reforming (SMR) at 4:1 and 3:2 ratio of $\mathrm{CH}_{4}: \mathrm{H}_{2} \mathrm{O}$ or $\mathrm{CO}_{2}$. 

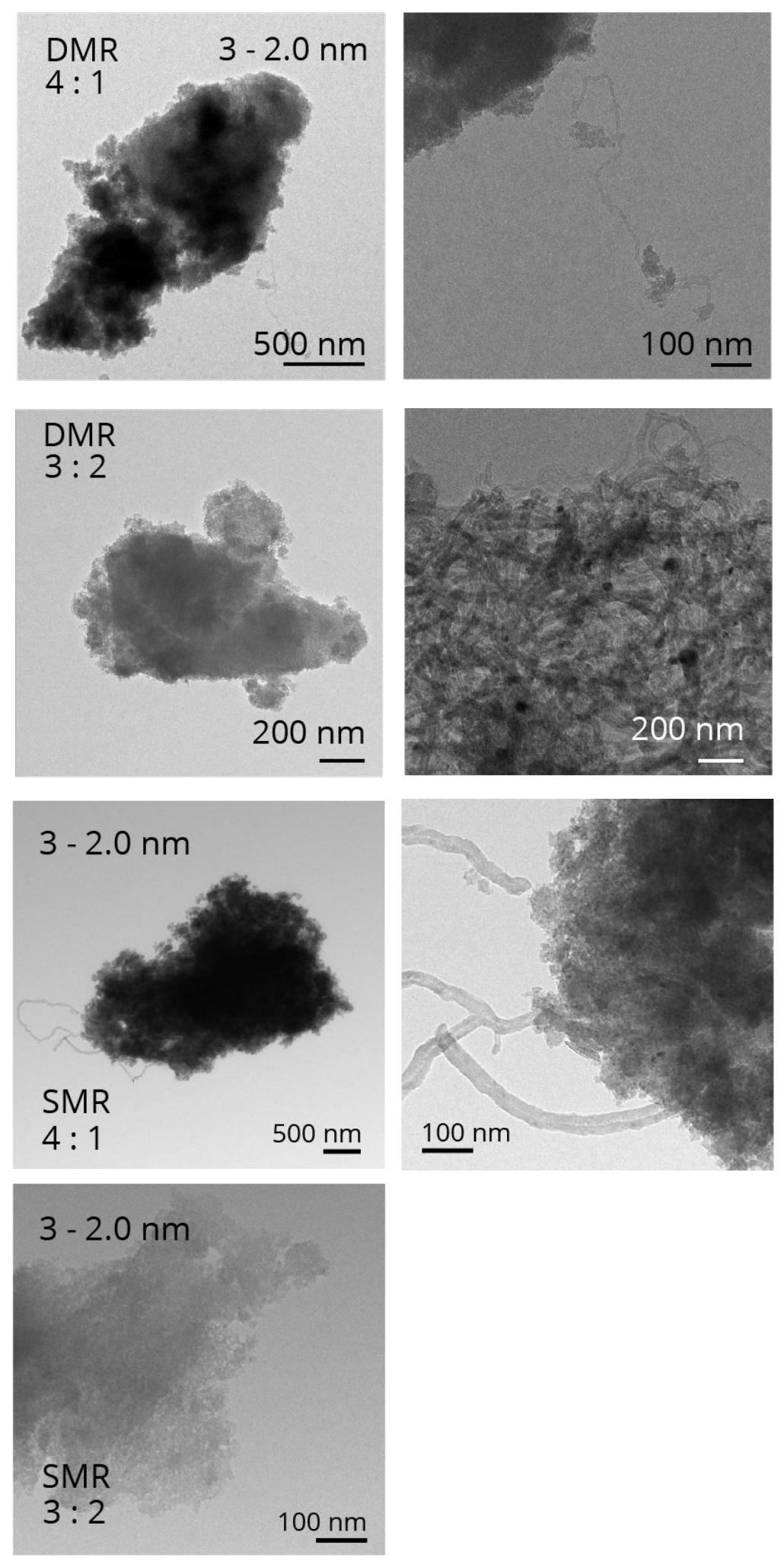

Figure S31. Representative transmission electron microscopy micrographs for $\mathrm{SiO}_{2}$ supported $\mathrm{Ni}$ catalyst sample 3 for dry methane reforming (DMR) and steam methane reforming (SMR) at 4:1 and 3:2 ratio of $\mathrm{CH}_{4}: \mathrm{H}_{2} \mathrm{O}$ or $\mathrm{CO}_{2}$.

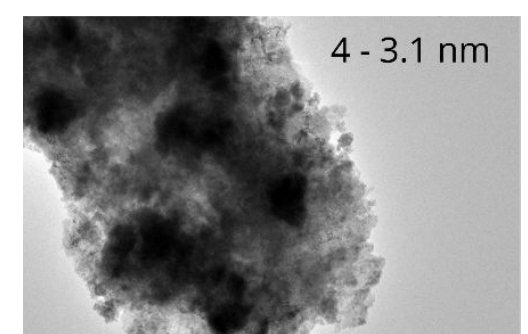



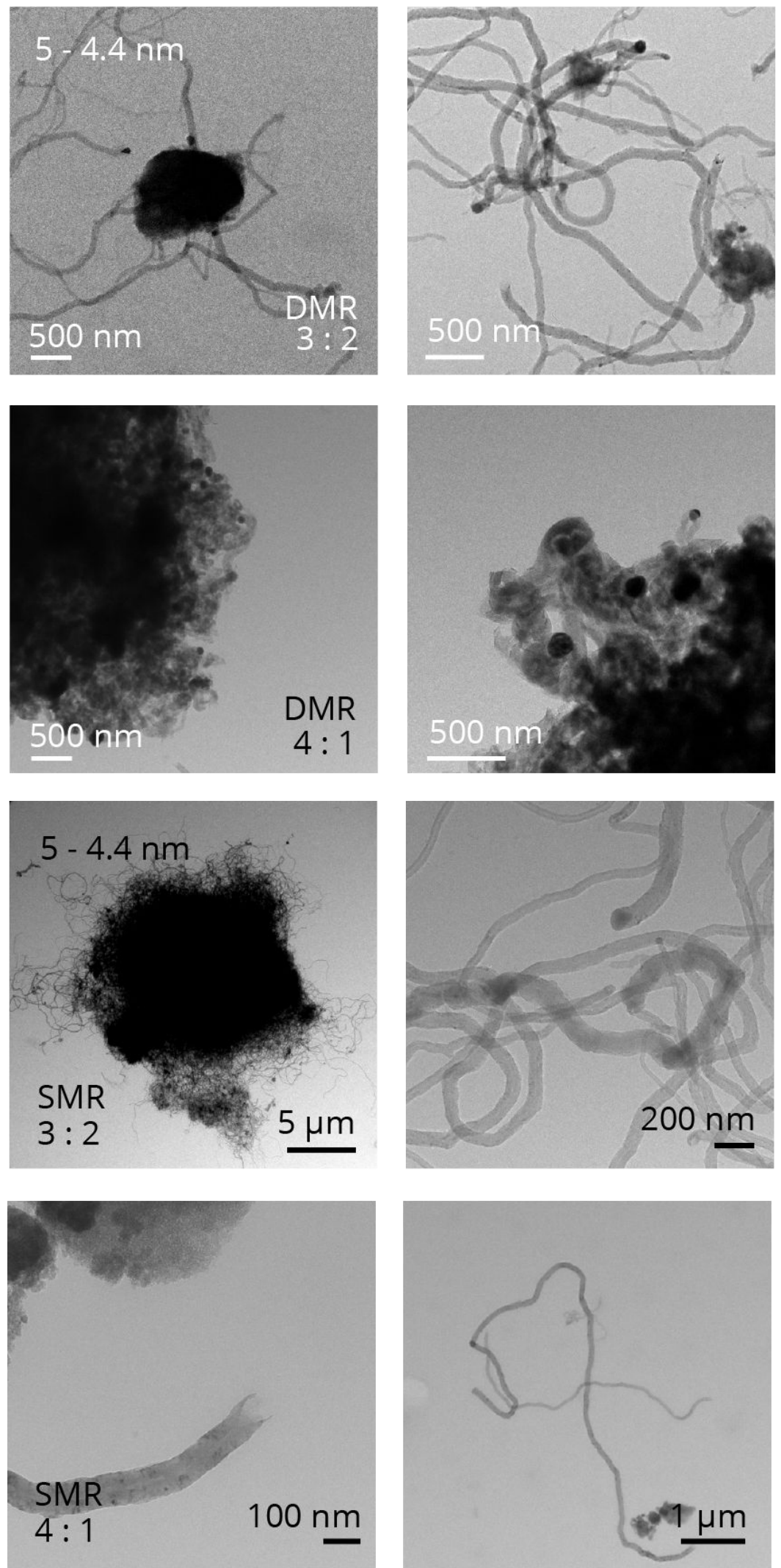

Figure S33. Representative transmission electron microscopy micrographs for $\mathrm{SiO}_{2}$ supported $\mathrm{Ni}$ catalyst sample 5 for dry methane reforming (DMR) and steam methane reforming (SMR) at 4:1 and 3:2 ratio of $\mathrm{CH}_{4}: \mathrm{H}_{2} \mathrm{O}$ or $\mathrm{CO}_{2}$. 

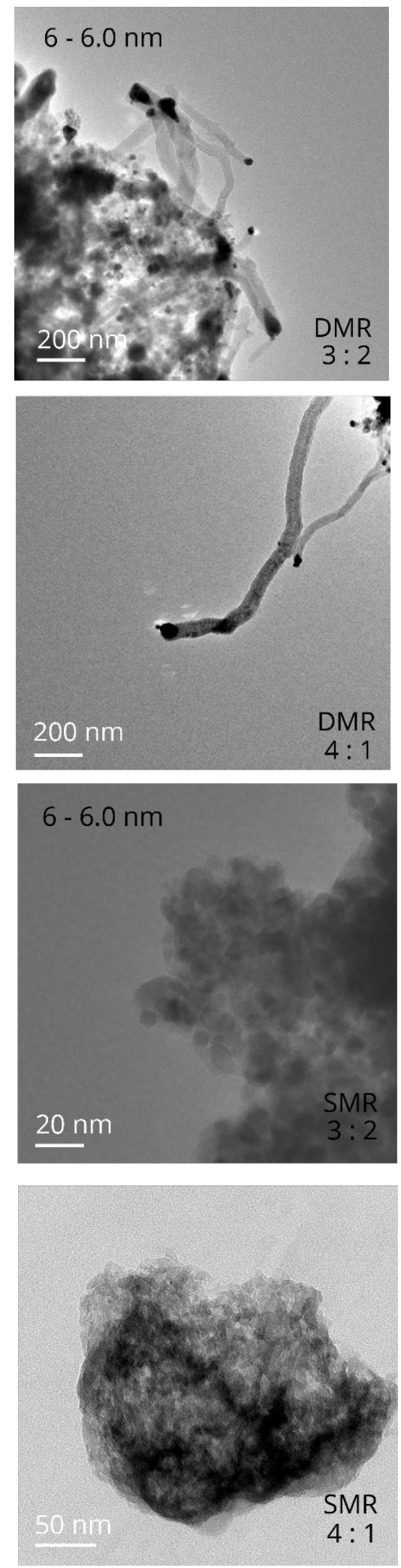

Figure S34. Representative transmission electron microscopy micrographs for $\mathrm{SiO}_{2}$ supported Ni catalyst sample 6 for dry methane reforming (DMR) and steam methane reforming (SMR) at 4:1 and 3:2 ratio of $\mathrm{CH}_{4}: \mathrm{H}_{2} \mathrm{O}$ or $\mathrm{CO}_{2}$. 

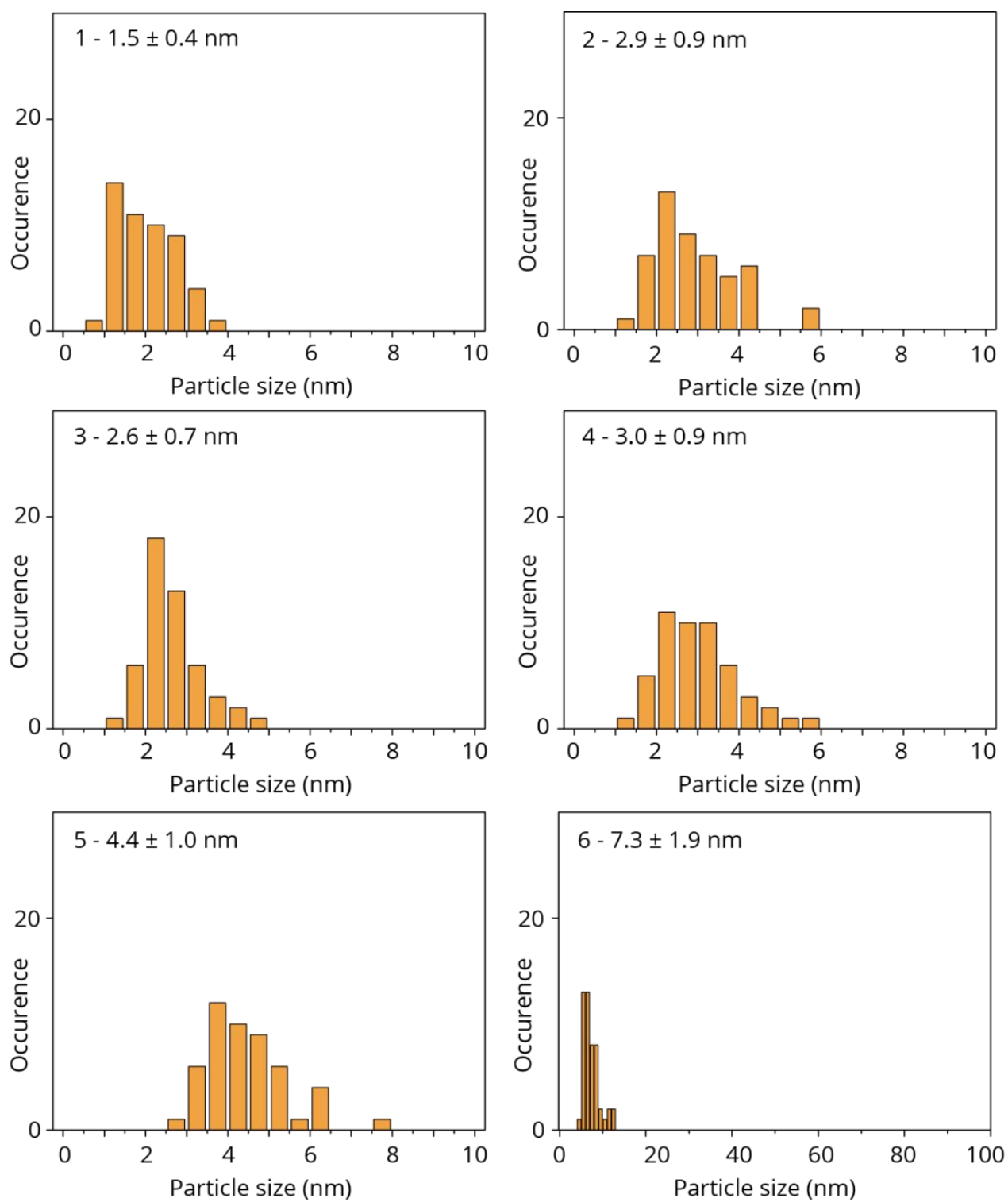

Figure S35. Particle size analysis from transmission electron microscopy counting of at least 50 particles for steam methane reforming in a ratio of $3: 2 \mathrm{CH}_{4}: \mathrm{H}_{2} \mathrm{O}$. 

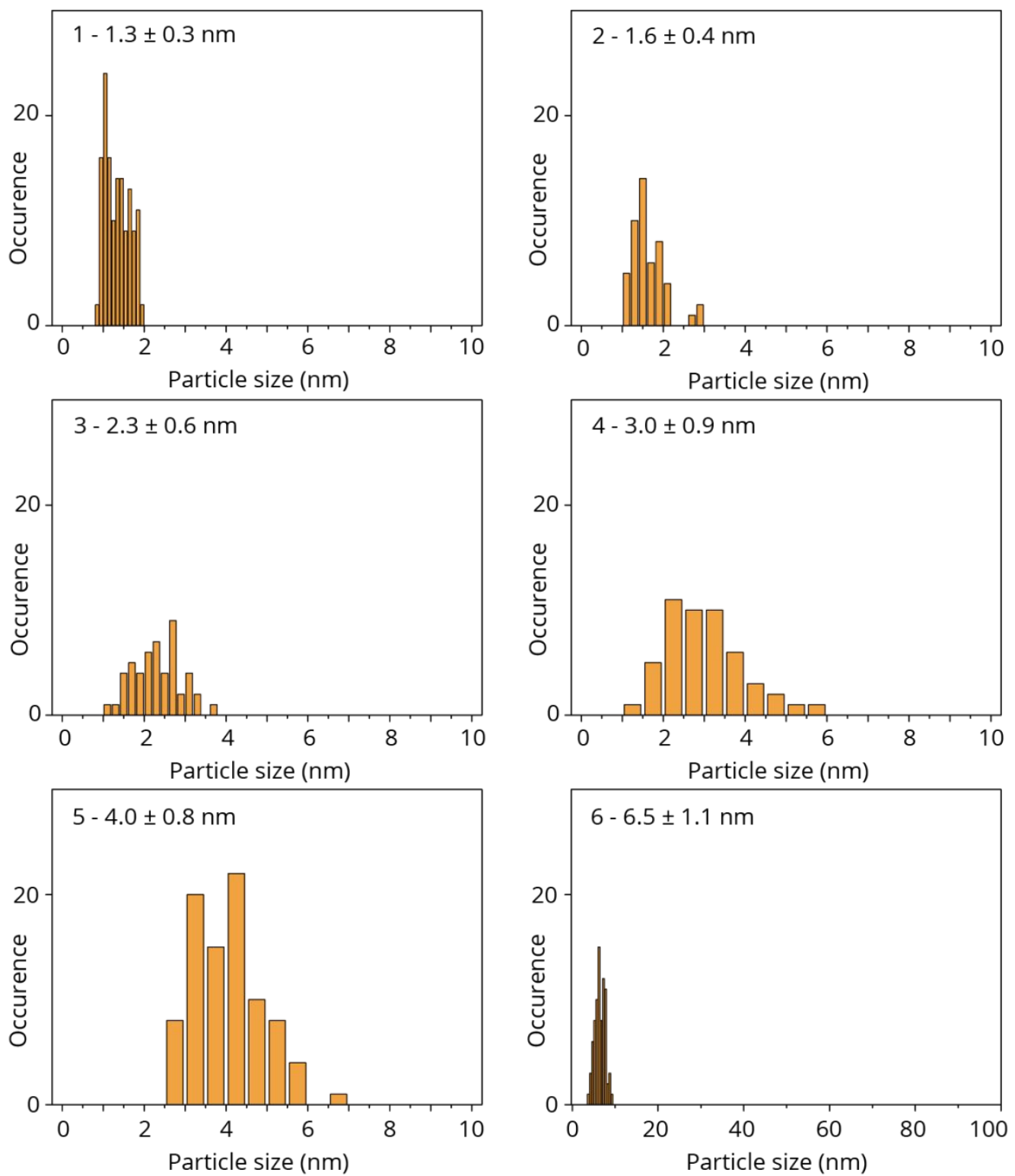

Figure S36. Particle size analysis from transmission electron microscopy counting of at least 50 particles for steam methane reforming in a ratio of $4: 1 \mathrm{CH}_{4}: \mathrm{H}_{2} \mathrm{O}$. 

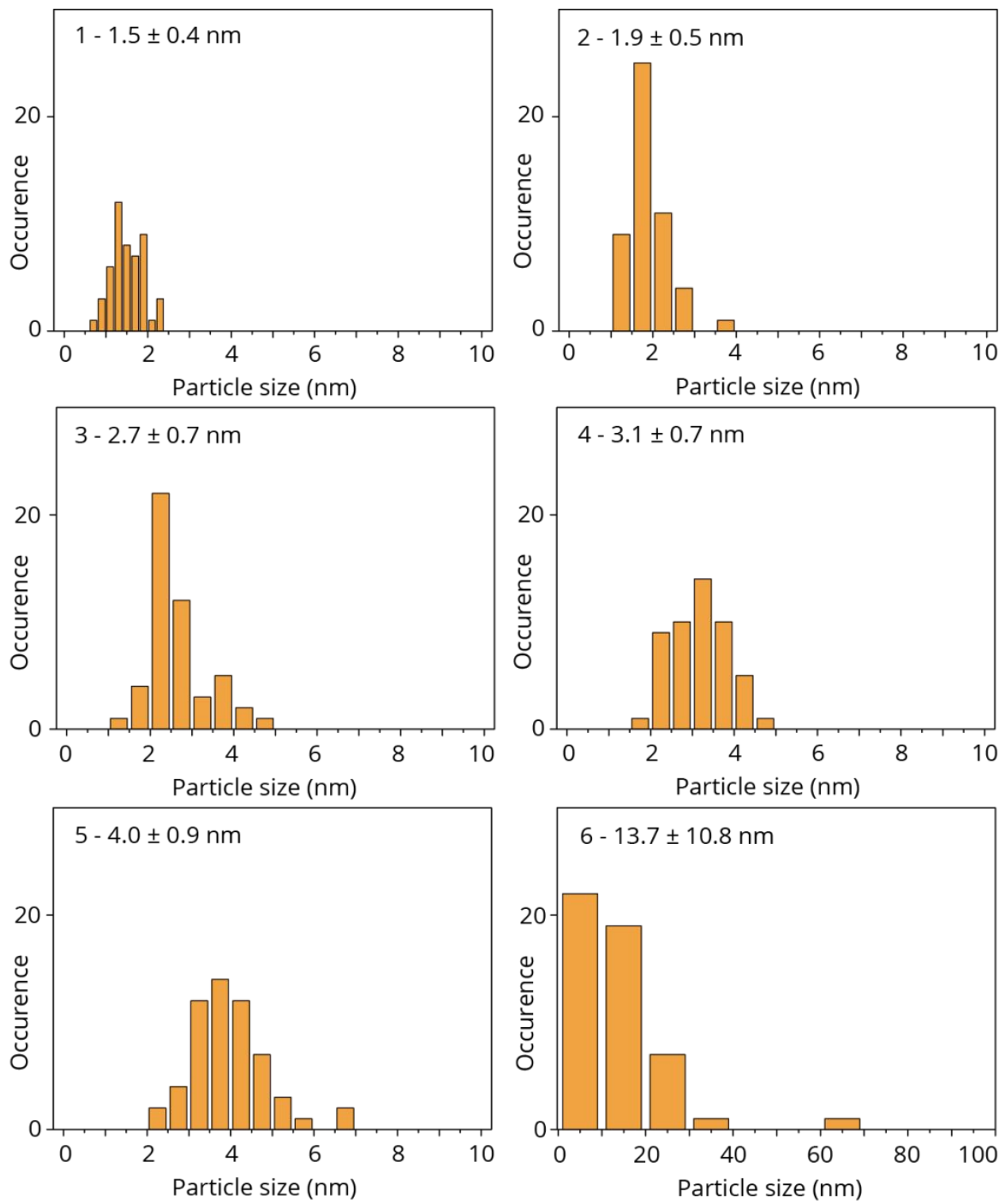

Figure S37. Particle size analysis from transmission electron microscopy counting of at least 50 particles for dry methane reforming in a ratio of $3: 2 \mathrm{CH}_{4}: \mathrm{CO}_{2}$. 


\section{References}

(1) Wei, J.; Iglesia, E. Structural Requirements and Reaction Pathways in Methane Activation and Chemical Conversion Catalyzed by Rhodium, J. Catal. 2004, 225, 116-127.

(2) Mark, M.; Maier, W. F. $\mathrm{CO}_{2}$ Reforming of Ethanol on Supportetd Rh Catalysts, J. Catal. 1996, 2, 4-5.

(3) Efstathiou, A. M.; Kladi, A.; Tsipouriari, V. A.; Verykios, X. E. Reforming of Methane with Carbon Dioxide to Synthesis Gas over Supported Rhodium Catalysts, J. Catal. 1996, 158, 64-75.

(4) Wei, J.; Iglesia, E. Mechanism and Site Requirements for Activation and Chemical Conversion of Methane on Supported Pt Clusters and Turnover Rate Comparisons among Noble Metals J. Phys. Chem. B 2004, 108, 4094 4103.

(5) Wei, J.; Iglesia, E. Isotopic and Kinetic Assessment of the Mechanism of Methane Reforming and Decomposition Reactions on Supported Iridium Catalysts, Phys.Chem.Chem.Phys. 2004, 6, 3754-3759.

(6) Yu, J.; Zhang, Z.; Dallmann, F.; Zhang, J.; Miao, D.; Xu, H.; Goldbach, A.; Dittmeyer, R. Facile Synthesis of Highly Active $\mathrm{Rh} / \mathrm{Al}_{2} \mathrm{O}_{3}$ Steam Reforming Catalysts With Preformed Support by Flame Spray Pyrolysis Appl. Catal. B Environ. 2016, 198, 171-179.

(7) Luna, E. C.; Becerra, A. M.; Dimitrijewits, M. I. Methane Steam Reforming over Rhodium Promoted Ni/ $/ \mathrm{Al}_{2} \mathrm{O}_{3}$ Catalysts, React. Kinet. Catal. Lett. 1999, 67, 247-252.

(8) Ramallo-López, J. M.; Requejo, F. G.; Craievich, A. F.; Wei, J.; Avalos-Borja, M.; Iglesia, E. Complementary Methods for Cluster Size Distribution Measurements: Supported Platinum Nanoclusters in Methane Reforming Catalysts, J. Mol. Catal. A Chem. 2005, 228, 299-307.

(9) Feio, L. S. F.; Hori, C. E.; Damyanova, S.; Noronha, F. B.; Cassinelli, W. H.; Marques, C. M. P.; Bueno, J. M. C. The Effect of Ceria Content on the Properties of $\mathrm{Pd} / \mathrm{CeO}_{2} / \mathrm{Al}_{2} \mathrm{O}_{3}$ Catalysts for Steam Reforming of Methane, Appl. Catal. A Gen. 2007, 316, 107-116.

(10) Wei, J.; Iglesia, E. Isotopic and Kinetic Assessment of the Mechanism of Reactions of $\mathrm{C}_{4}$ with $\mathrm{CO}_{2}$ or $\mathrm{H}_{2} \mathrm{O}$ to Form Synthesis Gas and Carbon on Nickel Catalysts J. Catal. 2004, 224, 370-383.

(11) Vogt, C.; Groeneveld, E.; Kamsma, G.; Nachtegaal, M.; Lu, L.; Kiely, C. J.; Berben, P. H.; Meirer, F.; Weckhuysen, B. M. Nat. Catal. 2018, 1, 127-134.

(12) Chumakova, A. V.; Valkovskiy, G. A.; Mistonov, A. A.; Dyadkin, V. A.; Grigoryeva, N. A.; Sapoletova, N. A.; Napolskii, K. S.; Eliseev, A. A.; Petukhov, A. V.; Grigoriev, S. V. Phys. Rev. B - Condens. Matter Mater. Phys. 2014, 90, 1-9.

(13) Frenkel, A. I.; Hills, C. W.; Nuzzo, R. G. A View from the Inside: Complexity in the Atomic Scale Ordering of Supported Metal Nanoparticles, J. Phys. Chem. B 2001, 105, 12689-12703.

(14) Ravel, B.; Newville, M. ATHENA, ARTEMIS, HEPHAESTUS: Data Analysis for X-ray Absorption Spectroscopy Using IFEFFIT J. Synchrotron Radiat. 2005, 12, 537-541.

(15) Schädle, T.; Pejcic, B.; Mizaikoff, B. Monitoring Dissolved Carbon Dioxide and Methane in Brine Environments at High Pressure Using IR-ATR Spectroscopy, Anal. Methods 2016, 8, 756-762.

(16) Rostrup-Nielsen, J. R. In Catalysis: Science and Technology; Eds. Anderson, J. R., Boudart, M., Springer-Verlag, Berlin, 1984, p 1-117.

(17) Kumar, M.; Ando, Y. Chemical Vapor Deposition of Carbon Nanotubes: A Review on Growth Mechanism and Mass Production, 2010, 10, 3739-3758.

(18) Baker, R. T. K.; Waite, R. J. Formation of Carbonaceous Deposits from the Platinum-Iron Catalyzed Decomposition of Acetylene, J. Catal. 1975, 37, 101-105. 